\title{
Synthesis of 3-(1,2,3-triazol-1-yl)- and 3-(1,2,3-triazol-4-yl)-substituted pyrazolo[3,4-d]pyrimidin-4-amines via click chemistry: potential inhibitors of the Plasmodium falciparum PfPK7 protein kinase
}

\author{
Michael Klein, ${ }^{a}$ Peter Dinér, ${ }^{a}$ Dominique Dorin-Semblat, ${ }^{b}$ Christian Doerig ${ }^{b}$ and Morten Grøtli*a \\ Received 1st April 2009, Accepted 27th May 2009 \\ First published as an Advance Article on the web 2nd July 2009 \\ DOI: 10.1039/b906482f
}

Efficient routes to 3-(1,2,3-triazol-1-yl)- and 3-(1,2,3-triazol-4-yl)pyrazolo[3,4- $d$ ]pyrimidin-4-amines using a one-pot two-step reaction are presented. The two routes give easy access to two different isomers of 1,4-disubstituted triazoles and the target compounds are obtained from a variety of readily available aromatic and aliphatic halides without isolation of potentially unstable organic azide intermediates. Two compounds show activity towards the PfPK7 kinase $\left(\mathrm{IC}_{50} 10-20 \mu \mathrm{M}\right)$ of $P$. falciparum, the organism responsible for the most virulent form of malaria, and can be regarded as hits useful for further development into lead compounds.

\section{Introduction}

The purine ring is the most ubiquitous nitrogen-containing heterocycle in nature, and it is the core structure of adenine and guanine in nucleic acids (RNA and DNA). ${ }^{1}$ In addition, purines are involved in many metabolic processes as the co-factors associated with a large number of enzymes and receptors, e.g. ATP and GTP, which play key roles in cell signalling and other fundamental biological processes. ${ }^{2}$

The ATP binding site in protein kinases is highly conserved, and therefore, the development of highly ATP competitive kinase inhibitors is a difficult task. However, there are regions within the binding cleft that are not occupied by ATP, and these regions (hydrophobic pockets) show a higher degree of structural diversity between members of the kinase family than the ATP binding regions. This provides opportunities for the discovery or design of selective and small molecule ATP-competitive inhibitors. ${ }^{3}$ For example, Shokat et al. have shown that the Abl kinase was effectively inhibited by the substituted 4-aminopyrazolo[3,4- $d]$ pyrimidine II, largely through interaction with such "non-ATP binding" pockets. ${ }^{4}$ Further, Pan et al. showed that compound I inhibits the Btk kinase in nanomolar concentration. ${ }^{5}$ The common motif for these 4-amino-pyrazolo[3,4- $d$ ]pyrimidine scaffolds is the "bent" geometry of the substituent in the 3-position of the pyrazole ring (Fig. 1). The bent structure allows the inhibitor to interact with the additional pocket of the active site, thereby increasing the inhibition and the specificity.

In our search for new scaffolds that could be used in the development of kinase inhibitors, we became interested in the 4-aminopyrazolo[3,4- $d$ ]pyrimidines. Our approach to 4aminopyrazolo[3,4- $d]$ pyrimidines involves the functionalisation

a'Department of Chemistry, University of Gothenburg, Kemivägen 10, 41296 Gothenburg, Sweden. E-mail: grotli@chem.gu.se; Fax: (+)46 31 7723840; Tel: $(+) 46317722905$

${ }^{b}$ INSERM Unit 609, Wellcome Centre for Molecular Parasitology, 120 University Place, Glasgow, UK G12 8TA and INSERM U609, Global Health Institute, Ecole Polytechnique Fédérale de Lausanne (EPFL), Station 19, CH-1015 Lausanne, Switzerland
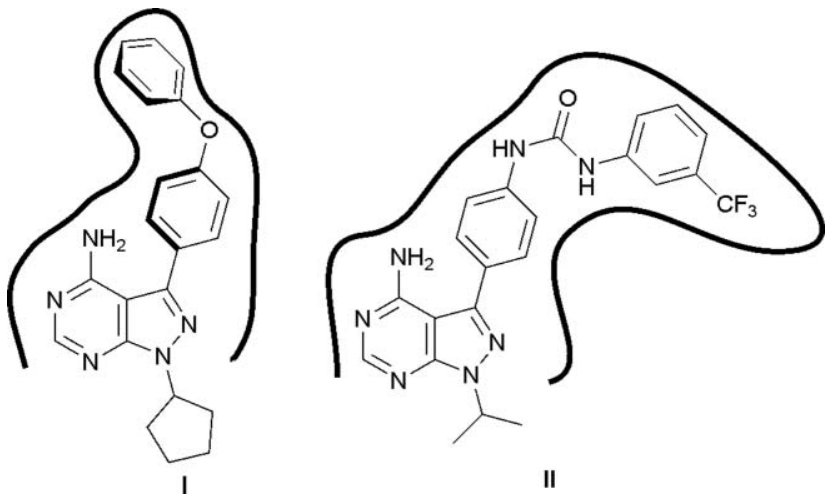

Fig. 1 Schematic picture of the binding of inhibitors 1 and 2 to the Btk kinase and the Abl kinase, respectively.

of the pyrazole ring in the 3-position with differently substituted triazole rings using a 1,4-regioselective copper-catalysed azidealkyne cycloaddition (CuAAC). ${ }^{6,7}$

The 1,3-dipolar cycloaddition, often referred to as click chemistry, has been used in various applications, e.g. organic synthesis, drug discovery, and chemical biology due to the high reaction yield and simple reaction and purification conditions of the "click chemistry", ${ }^{7-11}$

The use of click chemistry allows the 4-substituent of the 1,2,3-triazole ring to be easily varied through the use of different azides or alkynes. Furthermore, the 1,4-disubstituted triazoles will have the "bent" geometry that should be useful for targeting kinases with extended lipophilic pockets with a bent shape.

Here we wish to present two efficient routes to 3-(1,2,3-triazol-1yl)- and 3-(1,2,3-triazol-4-yl)-pyrazolo[3,4- $d$ ]pyrimidin-4-amines using a one-pot two-step reaction. The two routes developed give easy access to both 1- and 4-substituted triazole rings in the 3 -position of the pyrazole ring. Two compounds show activity in micromolar concentration $\left(\mathrm{IC}_{50} 10-20 \mu \mathrm{M}\right)$ towards the PfPK7 kinase in $P$. falciparum, the organism responsible for the most virulent form of malaria, and can be regarded as hits useful for further developments into lead compounds. 


\section{Results and discussion}

Starting from the common precursor 1, the target compounds 6 and 7 were synthesised according to two complementary strategies (Scheme 1). In Route 1, compound $\mathbf{2}$ is synthesised via the palladium-catalysed Sonogashira coupling followed by a coppercatalysed $[3+2]$-cycloaddition with an azide, resulting in the formation of target compound 3-(1,2,3-triazol-4-yl)-substituted pyrazolo[3,4- $d$ ]pyrimidin-4-amines $\mathbf{6}$. In Route 2 , compound $\mathbf{1}$ is converted into the azide $\mathbf{3}$, which is reacted in situ via the coppercatalysed $[3+2]$-cycloaddition with different alkynes resulting in formation of 3-(1,2,3-triazol-1-yl)-substituted pyrazolo[3,4d]pyrimidin-4-amines 7 .

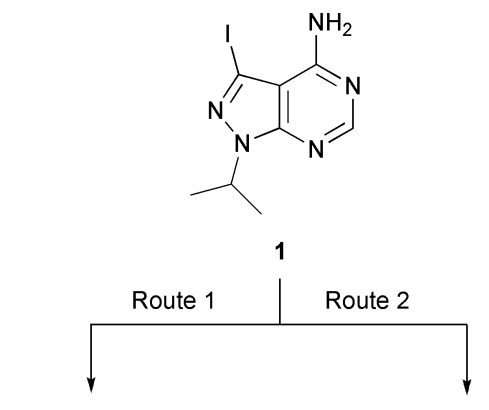<smiles>[Z]C(C)n1nc(C#C)c2c(N)ncnc21</smiles><smiles>CC(C)n1nc(N)c2c(N)ncnc21</smiles><smiles>Nc1ccbcc1</smiles>

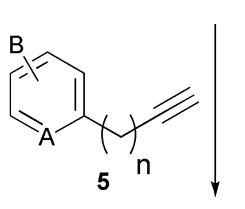<smiles>CC(C)n1nc(-c2cn(-c3ccbcc3)nn2)c2c(N)ncnc21</smiles>

6

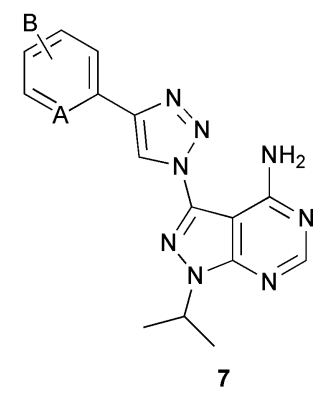

Scheme 1 Strategies for the synthesis of the target compounds 6 and 7.

From the starting material $\mathbf{1}$, the terminal alkyne $\mathbf{2}$ was synthesised according to two different procedures involving a Sonogashira coupling with a protected acetylene, followed by a deprotection of the alkyne (Scheme 2). Initially, 1 was reacted with TMS-acetylene in the presence of $\operatorname{Pd}\left(\mathrm{PPh}_{3}\right)_{4}(2 \mathrm{~mol} \%)$ and $\mathrm{CuI}(20 \mathrm{~mol} \%)$ in THF using microwave-assisted heating at $120^{\circ} \mathrm{C}$ to yield the protected alkyne $\mathbf{8}$ in excellent yield (91\%). In order to facilitate the work-up the weak ion exchange resin (IRA-67) was used as base, which after the reaction could simply be filtered off. The TMS-group was easily deprotected with sodium hydroxide in $\mathrm{THF} / \mathrm{MeOH}$ in good yield $(87 \%)$.
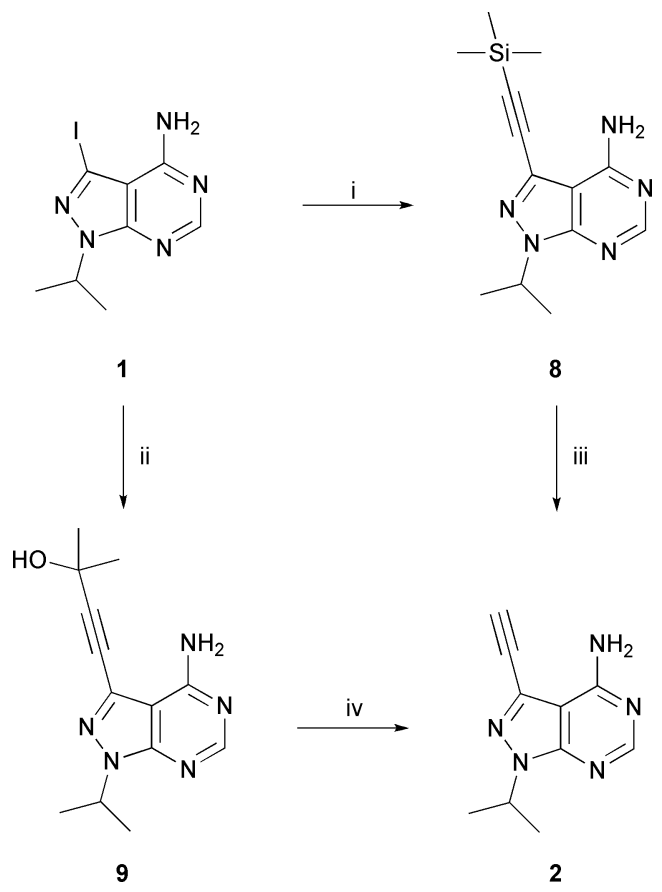

Scheme 2 (i) and (ii) Compound 1 (1-3 mmol), acetylene (4 eq.) $\mathrm{Pd}\left(\mathrm{PPh}_{3}\right)_{4}(2 \mathrm{~mol} \%), \mathrm{CuI}(20 \mathrm{~mol} \%)$ and Amberlite IRA-67 (5 eq.), THF, $\mathrm{MW}\left(120^{\circ} \mathrm{C}, 15 \mathrm{~min}\right)$. (iii) Compound $8, \mathrm{NaOH}(2 \mathrm{~N}), \mathrm{THF} / \mathrm{MeOH}(1: 1)$, r.t., 22 h. (iv) Compound $9, \mathrm{NaOH}$, toluene, reflux, $2 \mathrm{~h}$.

In some cases, the purification of compound $\mathbf{8}$ becomes difficult due to the formation of triphenylphosphine oxide in the reaction. Therefore, an alternative approach to the Sonogashira coupling was developed involving a different alkyne, 2-methyl-3-yn-2-ol. Under the same conditions as for the synthesis of compound $\mathbf{8}$, compound 9 was prepared in $74 \%$ yield. Due to the additional hydroxyl group, the resulting product is more polar than compound $\mathbf{8}$ and triphenylphosphine oxide could be removed completely with flash chromatography using chloroform/methanol as an eluent. Furthermore, the propargyl alcohol is much cheaper than TMS acetylene. Compound 9 was deprotected using catalytic amounts of sodium hydroxide in dry refluxing toluene yielding compound 2 in $91 \%$.

Since the synthesis of different organic azides is time consuming and in some cases very risky, several one-pot procedures have previously been developed. ${ }^{12,13}$ In these procedures, the organic azides are generated in situ either via the nucleophilic substitution of the alkyl halides by sodium azide or by the copper-catalysed reaction between an aromatic iodide and sodium azide, followed by the copper-catalysed [3+2]-cycloaddition reaction.

In order to find the optimal conditions for our reaction, a small screening of copper catalysts, solvents, reaction time and temperature was performed for the pyrazolo[3,4- $d]$ pyrimidine system (Table 1). Starting with the commonly used solvent system tert-butanol/water and copper sulfate with copper wire under microwave irradiation $\left(125^{\circ} \mathrm{C}, 15 \mathrm{~min}\right)$, formation of the product 6a was observed but the conversion was not complete according to ${ }^{1} \mathrm{H}$ NMR ( $66 \%$, entry 1$)$.

The solvents were changed to THF and DMF:water (4:1), but no reaction was observed and the starting material was fully recovered (entries 2 and 3). The influence of the copper catalyst was 
Table 1 Screening of different solvents, catalysts, and reaction conditions for the $\mathrm{Cu}(\mathrm{I})$-catalysed $[3+2]$ cycloaddition $^{a}$

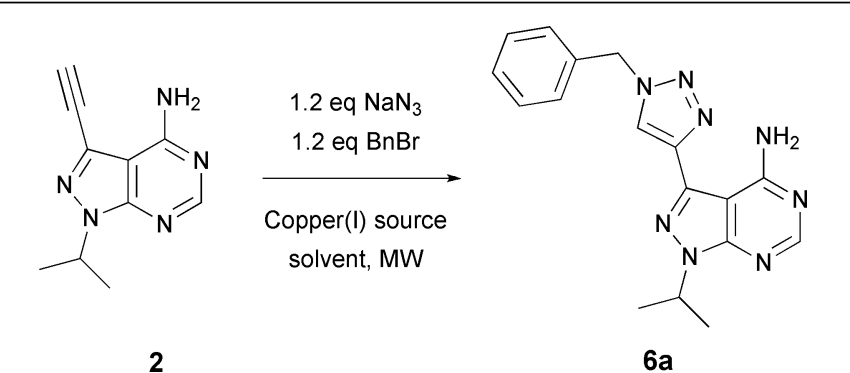

\begin{tabular}{|c|c|c|c|c|c|}
\hline Entry & Solvent & Cu-cat. & $\mathrm{T} /{ }^{\circ} \mathrm{C}$ & Time/min & Conv. $^{b}$ \\
\hline & ${ }^{\mathrm{t}} \mathrm{BuOH}: \mathrm{H}_{2} \mathrm{O}(1: 1)$ & $\mathrm{Cu}^{0}, \mathrm{CuSO}_{4}$ & 125 & 15 & $66: 33$ \\
\hline 2 & $\mathrm{THF}$ & $\mathrm{Cu}^{0}, \mathrm{CuSO}_{4}$ & 125 & 15 & n.r. \\
\hline 3 & DMF: $\mathrm{H}_{2} \mathrm{O}$ & $\mathrm{Cu}^{0}, \mathrm{CuSO}_{4}$ & 125 & 15 & n.r. \\
\hline 4 & DMF: $\mathrm{H}_{2} \mathrm{O}(4: 1)$ & $\mathrm{CuSO}_{4} / \mathrm{Naa}$ & 125 & 15 & $88: 12$ \\
\hline 5 & DMF: $\mathrm{H}_{2} \mathrm{O}(4: 1)$ & $\mathrm{CuSO}_{4} / \mathrm{Naasc}$ & 140 & 15 & Full conv. \\
\hline 6 & DMF: $\mathrm{H}_{2} \mathrm{O}(4: 1)$ & $\mathrm{CuSO}_{4} / \mathrm{Naasc}$ & 140 & 15 & $26: 1^{c}$ \\
\hline 7 & $\mathrm{DMF}: \mathrm{H}_{2} \mathrm{O}(4: 1)$ & $\mathrm{CuSO}_{4} / \mathrm{Naasc}$ & 125 & 30 & Full c \\
\hline
\end{tabular}

${ }^{a}$ Compound 2 ( $\left.0.25 \mathrm{mmol}\right)$, benzylbromide (1.2 eq.), $\mathrm{NaN}_{3}$ (1.2 eq.), solvents $(2 \mathrm{ml}), \mathrm{CuSO}_{4}\left(20 \mathrm{~mol}^{\%}, 1 \mathrm{M}\right.$ solution in $\left.\mathrm{H}_{2} \mathrm{O}\right)$, MW-heating (fixed hold-time). ${ }^{b}$ Determined by ${ }^{1} \mathrm{H}$ NMR (2:6a). ${ }^{c} 2.4$ eq. benzylbromide and azide.

investigated by exchanging the copper wire for sodium ascorbate (Naasc) (entries 3 and 4). Switching to copper sulfate/sodium ascorbate gave a high conversion (88:12) of the starting material (entry 4). The conversion was further improved by increasing the amount of alkylbromide (2.4 eq.) and sodium azide (2.4 eq.) and increasing the temperature to $140{ }^{\circ} \mathrm{C}$ (entries 5 and 6). Full conversion was also observed at $125^{\circ} \mathrm{C}$ after prolonged reaction time (entry 7).

With the optimised results in hand, compounds $6 \mathbf{a}-\mathbf{b}$ were synthesised in good to moderate yield (66-86\%, Scheme 3 ) using $\mathrm{CuSO}_{4}$ /sodium ascorbate $(20 \mathrm{~mol} \% / 40 \mathrm{~mol} \%)$ as the copper catalyst in a DMF: $\mathrm{H}_{2} \mathrm{O}(4: 1)$ solvent system and microwave irradiation for the heating $\left(130{ }^{\circ} \mathrm{C}, 30 \mathrm{~min}\right)$.

Using the same conditions, the aromatic iodides $\mathbf{4 c}-\mathbf{j}$ were reacted with alkyne $\mathbf{2}$ to give products $\mathbf{6} \mathbf{c}-\mathbf{j}$ in moderate to excellent yield (45-95\%) considering that the reaction is a two-step one-pot reaction.

The same one-pot procedure that was used in the synthesis of compounds $\mathbf{6 c}-\mathbf{j}$ was also used for the synthesis of compounds $\mathbf{7 a}-\mathbf{h}$ in which the azide $\mathbf{3}$ is generated in situ from compound $\mathbf{1}$ and then further reacts with the alkyne in the copper-catalysed [3 + 2]cycloaddition reaction to yield products $\mathbf{7 a}-\mathbf{h}$ (Scheme 4). The reactions proceeded in good to excellent yield for both aliphatic (5a-b) and aromatic alkynes (5c-h) (78-91\% yield), with the exception of the aromatic compounds $(\mathbf{5 f}-\mathbf{g})$ having an amine group and a nitro group substituent on the aromatic ring (58\% and $67 \%$, respectively).

\section{Biological evaluation of inhibitors towards the Plasmodium falciparum protein kinase PfPK7}

Recently, several X-ray structures of Plasmodium falciparum (P. falciparum) protein kinase 7 (PfPK7) in complex with different inhibitors have been disclosed. The molecules used in these

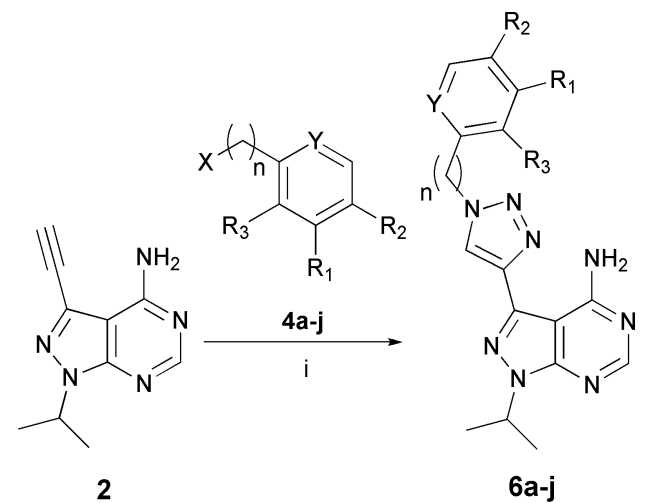

$$
\begin{aligned}
& \text { a } n=1, R_{1}=R_{2}=R_{3}=H, X=B r, Y=C H, 86 \% \\
& \text { b } n=2, R_{1}=R_{2}=R_{3}=H, X=B r, Y=C H, 66 \% \\
& \text { c } n=0, R_{1}=R_{2}=R_{3}=H, X=I, Y=C H, 95 \% \\
& \text { d } n=0, R_{1}=R_{3}=H, R_{2}=F, X=I, Y=C H, 65 \% \\
& \text { e } n=0, R_{1}=R_{3}=H, R_{2}=C l, X=I, Y=C H, 60 \% \\
& \text { f } n=0, R_{1}=R_{3}=H, R_{2}=O M e, X=I, Y=C H, 81 \% \\
& \text { g } n=0, R_{1}=R_{2}=R_{3}=H, X=I, Y=N, 48 \% \\
& \text { h } n=0, R_{1}=N_{2}, R_{2}=R_{3}=H, X=I, Y=C H, 52 \% \\
& \text { i } n=0, R_{1}=R_{2}=H, R_{3}=N O_{2}, X=I, Y=C H, 45 \% \\
& \text { j } n=0, R_{1}=R_{3}=H, R_{2}=M e, X=I, Y=C H, 76 \%
\end{aligned}
$$

Scheme 3 (i) Compound $2(0.25 \mathrm{mmol})$, alkyl bromide or aromatic iodide (1.2 eq.), $\mathrm{NaN}_{3}$ (1.2 eq.), DMF: $\mathrm{H}_{2} \mathrm{O}$ (4:1) (2.5 ml), $\mathrm{CuSO}_{4}(20 \mathrm{~mol} \%, 1 \mathrm{M}$ solution in $\left.\mathrm{H}_{2} \mathrm{O}\right)$, sodium ascorbate $(40 \mathrm{~mol} \%)$, MW-heating $\left(130{ }^{\circ} \mathrm{C}\right.$, $30 \mathrm{~min}$, fixed hold-time).
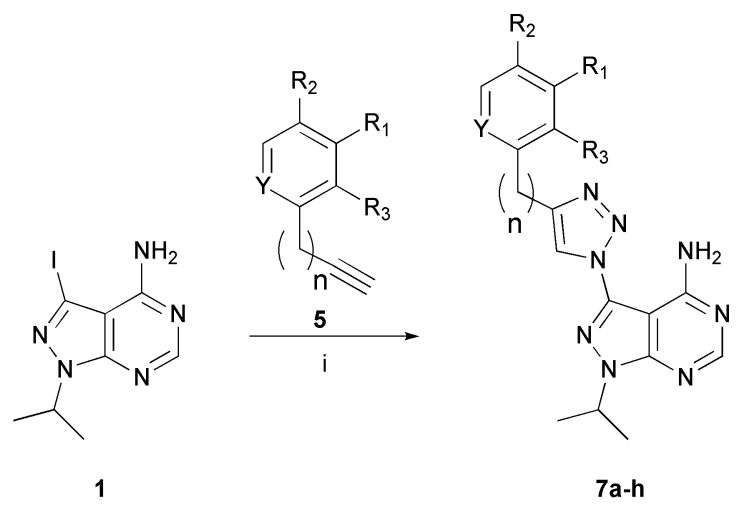

$$
\begin{aligned}
& \text { a } n=1, R_{1}=R_{2}=R_{3}=H, Y=C H, 87 \% \\
& \text { b } n=2, R_{1}=R_{2}=R_{3}=H, Y=C H, 84 \% \\
& \text { c } n=0, R_{1}=R_{2}=R_{3}=H, Y=C H, 91 \% \\
& \text { d } n=0, R_{1}=R_{3}=H, R_{2}=O M e, Y=C H, 78 \% \\
& \text { e } n=0, R_{1}=R_{3}=H, R_{2}=M e, Y=C H, 90 \% \\
& \text { f } n=0, R_{1}=N_{2}, R_{2}=R_{3}=H, Y=C H, 58 \% \\
& \text { g } n=0, R_{1}=R_{2}=H, R_{3}=N O_{2}, Y=C H, 67 \% \\
& \text { h } n=0, R_{1}=R_{2}=R_{3}=H, Y=N, 78 \%
\end{aligned}
$$

Scheme 4 (i) Alkyne 5 (0.25 mmol), compound 1, (1.2 eq.), $\mathrm{NaN}_{3}$ (1.2 eq.), DMF: $\mathrm{H}_{2} \mathrm{O}(4: 1)(2.5 \mathrm{ml}), \mathrm{CuSO}_{4}\left(20 \mathrm{~mol} \%, 1 \mathrm{M}\right.$ solution in $\left.\mathrm{H}_{2} \mathrm{O}\right)$, sodium ascorbate (40 $\mathrm{mol} \%)$, MW-heating $\left(130^{\circ} \mathrm{C}, 30 \mathrm{~min}\right.$, fixed hold-time).

structural studies included compounds based on the same pyrazolopyrimidine scaffold as presented in this work. ${ }^{14,15}$ Therefore, we were interested in investigating the potential use of our compounds as leads towards PfPK7 inhibitors.

$P$. falciparum is the most virulent species of human malaria parasites and is responsible for the most severe forms of the disease. 
Malaria causes over two million deaths annually, predominantly among children from sub-Saharan Africa. P. falciparum is becoming resistant to currently available antimalarial treatments, which has led to an urgent and continuing search for new methods of control. ${ }^{16,17}$ Within malaria parasites, inhibition of protein kinases can modulate intracellular protein phosphorylation events, just as in other eukaryotes. Some P. falciparum kinases are not related to any eukaryote protein kinase family, and these may be validated as potential P. falciparum-specific drug targets. ${ }^{18,19}$ One such emerging target is PfPK7, an 'orphan' plasmodial kinase which is distantly related to the MAPKK family of kinases (mitogen-activated protein kinase kinase). ${ }^{20,21}$ Disruption of the $p f p k 7$ gene suggests that PfPK7 is involved in a pathway regulating cell proliferation and development: P. falciparum clones in which the PfPK 7 locus has been inactivated are viable, but their asexual growth rate is about half that observed in wild-type parasites. ${ }^{22}$ This phenotype suggests that PFPK7 inactivation through chemical inhibition would be expected to slow parasite growth and, hence, decrease the virulence of infection.

The effect of molecules $\mathbf{6 a}-\mathbf{i}$ and $\mathbf{7 a}-\mathbf{h}$ on the activity of recombinant PfPK7 was tested in in vitro inhibition assays and an initial test was performed at $10 \mu \mathrm{M}$ for compounds $\mathbf{6 a}-\mathbf{i}$ and $7 \mathbf{a}-\mathbf{h}$. The assay measured the efficacy of compounds 6a-i and $7 \mathbf{a}-\mathbf{h}$ at decreasing myelin basic protein (MBP, the exogenous substrate used in the assay) phosphorylation, as semiquantitatively determined by autoradiography (Fig. 2).

\section{Effect of 17 compounds on GST-PfPK7 activity}

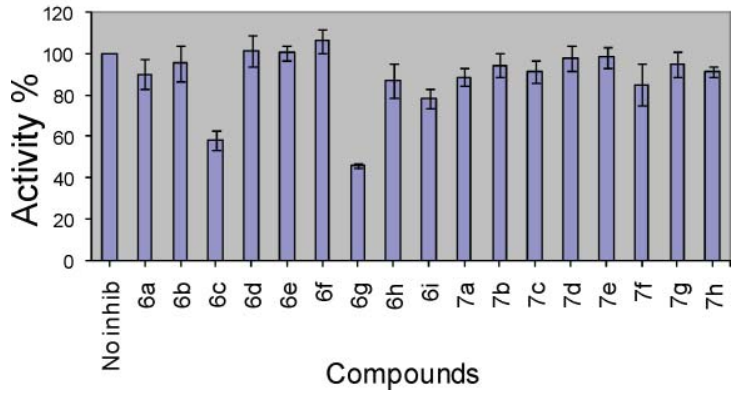

Fig. 2 Inhibition of recombinant PfPK7 by compounds 6a-i and 7a-h. The efficacies are the averages from three measurements at $10 \mu \mathrm{M}$ compound concentration. See Experimental procedures for details.

Two of the compounds, $\mathbf{6 c}$ and $\mathbf{6 g}$, showed a significant decrease in MBP phosphorylation at $10 \mu \mathrm{M}$ concentration and $\mathrm{IC}_{50}$ values for these compounds were determined to be $\sim 20$ and $\sim 10 \mu \mathrm{M}$, respectively (Fig. 3). Interestingly, although activity was significantly decreased in the presence of micromolar range concentrations of the inhibitors, we were unable to completely inhibit the kinase with the compounds, even at $1 \mathrm{mM}$. Nevertheless, these results demonstrate that the molecules with the pyrazolopyrimidine scaffold developed in this study do indeed affect PfPK7 activity.

To understand the binding mode of the active compounds, we docked 6c (Glide, XP mode) into the X-ray structure of PfPK7 (2PML) ${ }^{23,24}$ The pyrazolopyrimidine scaffold was superimposed with the adenylyl imidodiphosphate (AMP-PNP) ligand in the $\mathrm{X}$-ray structure and the protein-ligand complex was optimised using the OPLS force field. ${ }^{24}$
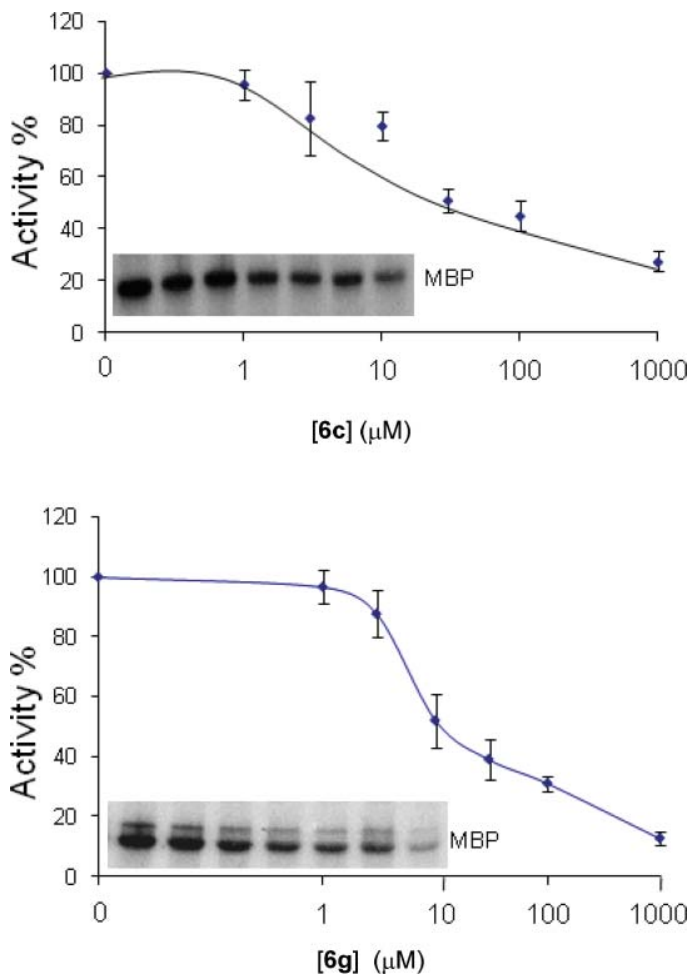

Fig. 3 Inhibition of recombinant PfPK7 by compounds 6c (top panel) and $\mathbf{6 g}$ (bottom panel). The autoradiographic data (MBP phosphorylation) used to construct the curves are shown as insets. See Experimental procedures for details.

The pyrazolopyrimidine ring is buried within the active site and makes one hydrogen bond with PfPK7 to the backbone amide group of Met120 within the hinge region and another hydrogen bond to the backbone carbonyl moiety of Glu118, which is a similar binding to that seen for the AMPPNP ligand in the X-ray structure (Fig. 4). In PfPK7, a hydrophobic pocket is accessible to ATP-competitive inhibitors, which has previously been shown in X-ray structures of PfPK $7 .{ }^{15}$ The docking suggests that the

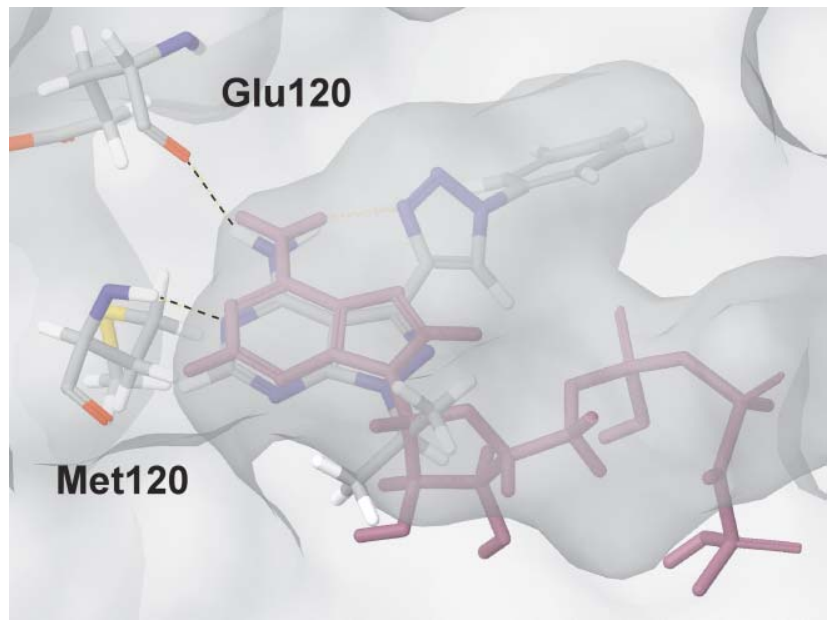

Fig. 4 Docking of compound 6 c into the ATP-pocket of PfPK7 (purple: AMP-PNP). Compound $\mathbf{6 c}$ is suggested to have the same binding mode as ATP and to also bind to the additional hydrophobic part of the ATP pocket. 
4-phenyl-(1,2,3-triazol-1-yl)-moiety of compound $\mathbf{6 c}$ binds to the hydrophobic pocket within the ATP cleft and could explain the inhibitory effect of compound $\mathbf{6 c}$.

\section{Conclusions}

An efficient strategy for the preparation of of 3-(1,2,3-triazol1-yl)- and 3-(1,2,3-triazol-4-yl)pyrazolo[3,4- $d$ ]pyrimidin-4-amines has been developed. The target compounds are obtained by a convenient one-pot procedure from a variety of readily available aromatic and aliphatic halides without isolation of potentially unstable organic azide intermediates. Two compounds show activity towards the PfPK7 kinase $\left(\mathrm{IC}_{50} 10-20 \mu \mathrm{M}\right)$ in P. falciparum, the organism responsible for the most virulent form of malaria. These are some of the very few inhibitors identified targeting the PfPK7 kinase and should be useful starting points for further development into lead compounds.

\section{Experimental part}

\section{General}

${ }^{1} \mathrm{H}(400 \mathrm{MHz})$ and ${ }^{13} \mathrm{C}(100 \mathrm{MHz}) \mathrm{NMR}$ spectra were obtained from a JEOL JNM-EX 400 spectrometer. The symbol "+" indicates $\mathrm{CH}_{3}$ and $\mathrm{CH}$ groups identified from distortionless enhancement of polarisation transfer (DEPT) spectra. Column chromatography was performed by manual flash chromatography (wet packed silica, $0.04-0.063 \mathrm{~mm}$ ) or by automated column chromatography on Biotage SP-4 using pre-packed columns. Microwave reactions were performed in a Biotage Initiator reactor with fixed hold time. IR spectra were recorded on a PerkinElmer 16 PC spectrometer. Elemental analyses were performed at Kolbe Mikroanalytisches Laboratorium, Mülheim and der Ruhr, Germany. X-ray structures with inhibitors were used as starting point for all dockings. The PfPK 7 kinase was prepared according to the standard procedure in the Schrödinger package. Docking was performed by using Glide (Schrödinger) with extraprecision (XP) settings and standard parameters for ligand docking.

\section{4-Amino-3-iodo-1-(isopropyl)pyrazolo $[3,4-d]$ pyrimidine (1)}

4-Amino-3-iodo-pyrazolo[3,4-d]pyrimidine (2000 mg, $7.66 \mathrm{mmol}$ ) and $\mathrm{K}_{2} \mathrm{CO}_{3}(2115 \mathrm{mg}, 15.32 \mathrm{mmol})$ were suspended in $12 \mathrm{ml}$ of dry DMF in a $20 \mathrm{ml}$ microwave vessel. To this mixture, 2-chloropropane $(0.77 \mathrm{ml}, 662 \mathrm{mg}, 8.426 \mathrm{mmol})$ were added and the sealed tube was heated to $200{ }^{\circ} \mathrm{C}$ for $5 \mathrm{~min}$. (20 s of pre-stirring and fixed hold time: on). After cooling of the reaction mixture to room temperature, additional 2-chloropropane $(0.35 \mathrm{ml}, 301 \mathrm{mg}$, $3.83 \mathrm{mmol})$ was added and the microwave vessel was heated again to $200{ }^{\circ} \mathrm{C}$ for $5 \mathrm{~min}$. After cooling to ambient temperature, the reaction mixture was diluted with DMF and filtered. The solvent was removed in vacuo at $80{ }^{\circ} \mathrm{C}$ and the residue was co-distilled with toluene three times. The crude product was purified by flash column chromatography on silica gel $(\mathrm{MeOH}$ : $\left.\mathrm{CHCl}_{3}=1: 20\right)$ to give $2205 \mathrm{mg}(95 \%)$ of 2 as fine yellow needles. $\mathrm{R}_{\mathrm{f}}\left(\mathrm{MeOH}: \mathrm{CHCl}_{3}=1: 40\right)=0.29$. Mp 203-204 ${ }^{\circ} \mathrm{C} .{ }^{1} \mathrm{H} \mathrm{NMR}$ $\left(400 \mathrm{MHz}, \mathrm{CDCl}_{3}\right) \delta 1.55 \mathrm{ppm}\left(\mathrm{d},{ }^{3} J_{\mathrm{HH}}=6.6 \mathrm{~Hz}, 6 \mathrm{H}\right), 5.09$ (sept, $\left.{ }^{3} J_{\mathrm{HH}}=6.6 \mathrm{~Hz}, 1 \mathrm{H}\right), 6.17\left(\mathrm{bs}, 2 \mathrm{H},-\mathrm{NH}_{2}\right), 8.32(\mathrm{~s}, 1 \mathrm{H}) .{ }^{13} \mathrm{C} \mathrm{NMR}$ $\left(100 \mathrm{MHz} \mathrm{CDCl}_{3}\right) \delta 22.27 \mathrm{ppm}(+), 49.89(+), 85.62\left(\mathrm{C}_{\text {quart }}\right), 104.25$ $\left(\mathrm{C}_{\text {quart }}\right), 153.17\left(\mathrm{C}_{\text {quart }}\right), 155.88(+), 157.63\left(\mathrm{C}_{\text {quart }}\right)$. Anal. Calcd for
$\mathrm{C}_{8} \mathrm{H}_{10} \mathrm{IN}_{5}$ (302.9981): C, 31.70; H, 3.33; N, 23.11. Found C, 31.84; H, 3.40; N, 23.19.

\section{General procedure A for preparation of 3-ethynyl substituted 4-amino-1-isopropyl-1 $H$-pyrazolo[3,4- $d]$ pyrimidines (8 and 9)}

4-Amino-3-iodo-1-isopropyl-1 $H$-pyrazolo[3,4- $d]$ pyrimidine 1 (1$3 \mathrm{mmol}), \mathrm{Pd}\left(\mathrm{PPh}_{3}\right)_{4}(2 \mathrm{~mol} \%), \mathrm{CuI}\left(20 \mathrm{~mol}^{\%}\right)$ and Amberlite IRA67 (5 eq.) were suspended in of THF (12 ml) in a $20 \mathrm{ml}$ microwave vessel. To the stirring mixture the appropriate acetylene (4 eq.) was added, the vessel was sealed and heated to $120^{\circ} \mathrm{C}$ for $15 \mathrm{~min}$ (ramp time: $240 \mathrm{~s}$, pre-stirring: $20 \mathrm{~s}$, high, fixed hold time: on). After cooling to room temperature, the reaction mixture was filtered through Celite and washed with $\mathrm{CHCl}_{3}$. The solvent was removed in vacuo at $30{ }^{\circ} \mathrm{C}$. The crude product was purified by flash column chromatography on silica gel $\left(\mathrm{MeOH}: \mathrm{CHCl}_{3}=1: 20\right)$.

\section{4-Amino-1-isopropyl-3-trimethylsilanylethynyl-1 $H$-pyrazolo[3,4- d]pyrimidine (8)}

Compound 1 (981 mg, $3.237 \mathrm{mmol}$ ) was converted to compound $8\left(800 \mathrm{mg}, 91 \%\right.$ yield) by general procedure A. $\mathrm{R}_{\mathrm{f}}\left(\mathrm{MeOH}: \mathrm{CHCl}_{3}\right.$ $1: 40)=0.21 .{ }^{1} \mathrm{H}$ NMR $\left(400 \mathrm{MHz}, \mathrm{CDCl}_{3}\right) \delta 0.28 \mathrm{ppm}(\mathrm{s}, 9 \mathrm{H}$, -Si- $\left.\left(\mathrm{CH}_{3}\right)_{3}\right), 1.54\left(\mathrm{~d},{ }^{3} \mathrm{~J}_{\mathrm{HH}}=6.6 \mathrm{~Hz}, 6 \mathrm{H}, \mathrm{CH}_{3}-\mathrm{CH}\right), 5.10$ (sept, $\left.{ }^{3} J_{\mathrm{HH}}=6.6 \mathrm{~Hz}, 1 \mathrm{H}, \mathrm{CH}_{3}-\mathrm{CH}-\mathrm{N}\right), 8.31(\mathrm{~s}, 1 \mathrm{H}, \mathrm{N}-\mathrm{CH}-\mathrm{N}) \cdot{ }^{13} \mathrm{C} \mathrm{NMR}$ $\left(100 \mathrm{MHz}, \mathrm{CDCl}_{3}\right) \delta-0.15 \mathrm{ppm}\left(+,-\mathrm{Si}-\left(\mathrm{CH}_{3}\right)_{3}\right), 22.14\left(+, \mathrm{CH}_{3}-\right.$ $\mathrm{CH}), 49.61\left(+, \mathrm{CH}_{3}-\mathrm{CH}-\mathrm{N}\right), 96.69\left(\mathrm{C}_{\text {quart }}\right), 100.94\left(\mathrm{C}_{\text {quart }}\right), 102.34$ $\left(\mathrm{C}_{\text {quart }}\right), 125.97\left(\mathrm{C}_{\text {quart }}\right), 152.45\left(\mathrm{C}_{\text {quart }}\right), 156.28(+), 158.10\left(\mathrm{C}_{\text {quart }}\right) . \mathrm{IR}$ $(\mathrm{KBr}) \mathrm{v}=3453 \mathrm{~cm}-1,3326,3113,2975,2163,1657,1595,1574$, 1252, 862, 846. Anal. Calcd for $\mathrm{C}_{13} \mathrm{H}_{19} \mathrm{~N}_{5} \mathrm{Si}$ : C, 57.11; H, 7.00; N, 25.61. Found C, 57.24; H, 7.10; N, 25.48.

\section{4-(4-Amino-1-isopropyl-1 $H$-pyrazolo[3,4- $d]$ pyrimidin-3-yl)-2- methyl-but-3-yn-2-ol (9)}

The general procedure A using 1 (303 mg, $1.000 \mathrm{mmol})$ afforded $192 \mathrm{mg}(74 \%)$ of 9 as colorless solid. $\mathrm{R}_{\mathrm{f}}\left(\mathrm{MeOH}: \mathrm{CHCl}_{3}=\right.$ $1: 40)=0.21 .{ }^{1} \mathrm{H}$ NMR $\left(400 \mathrm{MHz}, \mathrm{CDCl}_{3}\right) \delta 1.46 \mathrm{ppm}(\mathrm{d}$, $\left.{ }^{3} J_{\mathrm{HH}}=6.6 \mathrm{~Hz}, 6 \mathrm{H}, \mathrm{CHN}-\left(\mathrm{CH}_{3}\right)_{2}\right), 1.62\left(\mathrm{~s}, 6 \mathrm{H}, \mathrm{CCO}-\left(\mathrm{CH}_{3}\right)_{2}\right), 5.02$ (sept, $\left.{ }^{3} J_{\mathrm{HH}}=6.6 \mathrm{~Hz}, 1 \mathrm{H},\left(\mathrm{CH}_{3}\right)_{2}-\mathrm{CH}-\mathrm{N}\right), 8.21(\mathrm{~s}, 1 \mathrm{H}, \mathrm{N}-\mathrm{CH}-\mathrm{N})$. ${ }^{13} \mathrm{C} \mathrm{NMR}\left(100 \mathrm{MHz}, \mathrm{CDCl}_{3}\right) \delta=22.01 \mathrm{ppm}\left(+, \mathrm{CHN}-\left(\mathrm{CH}_{3}\right)_{2}\right)$, $31.33\left(+,-\mathrm{CCO}-\left(\mathrm{CH}_{3}\right)_{2}\right), 49.51\left(+, \mathrm{CH}_{3}-\mathrm{CH}-\mathrm{CH}_{3}\right), 65.33\left(\mathrm{C}_{\text {quart }}\right)$, $74.12\left(\mathrm{C}_{\text {quart }}\right), 99.68\left(\mathrm{C}_{\text {quart }}\right), 101.81\left(\mathrm{C}_{\text {quart }}\right), 125.69\left(\mathrm{C}_{\text {quart }}\right), 152.04$ $\left(\mathrm{C}_{\text {quart }}\right), 155.84(+), 157.95\left(\mathrm{C}_{\text {quart }}\right)$. IR (film) $\vee 3459 \mathrm{~cm}^{-1}, 3329$, 2981, 2934, 1638, 1573. Anal. Calcd for $\mathrm{C}_{13} \mathrm{H}_{17} \mathrm{~N}_{5} \mathrm{O}: \mathrm{C}, 60.21 ; \mathrm{H}$, 6.61; N, 27.01. Found C, 60.23; H,6.64; N, 27.04.

\section{4-Amino-1-isopropyl-3-ethynyl-1 $H$-pyrazolo[3,4-d]pyrimidine (2)}

Method 1. Alcohol 9 (151 mg, $0.582 \mathrm{mmol})$ was suspended in $5 \mathrm{ml}$ of dry toluene (dried over $\mathrm{Na}$ /benzophenone) and crushed $\mathrm{NaOH}(84 \mathrm{mg}, 2.10 \mathrm{mmol})$ was added. The reaction mixture was stirred at reflux for $2 \mathrm{~h}$. The solvent was removed in vacuo at $30{ }^{\circ} \mathrm{C}$ and the residue was purified by flash column (MeOH: $\left.\mathrm{CHCl}_{3}=1: 80\right)$ to give $106 \mathrm{mg}(91 \%)$ of 2 as a pale brownish solid.

Method 2. Compound 8 (713 mg, $2.61 \mathrm{mmol})$ was dissolved in THF $(20 \mathrm{ml})$ and $\mathrm{MeOH}(15 \mathrm{ml})$ and $2 \mathrm{~N} \mathrm{NaOH}$ was added and the reaction mixture was stirred at room temperature. After $22 \mathrm{~h}$, the reaction was quenched by the addition of $30 \mathrm{ml}$ of 
brine. The mixture was extracted with EtOAc $(3 \times 60 \mathrm{ml})$. The combined, organic layers were dried over $\mathrm{MgSO}_{4}$ and the solvent was removed in vacuo. The crude product was purified with flash column chromatography on silica gel ( $\left.\mathrm{MeOH}: \mathrm{CHCl}_{3}=1: 40\right)$ to give $454 \mathrm{mg}(87 \%)$ of $\mathbf{2}$ as a pale colored solid. $\mathrm{R}_{\mathrm{f}}(\mathrm{MeOH}$ : $\left.\mathrm{CHCl}_{3}=1: 40\right)=0.18 . \mathrm{Mp} 188-189{ }^{\circ} \mathrm{C} .{ }^{1} \mathrm{H}$ NMR $(400 \mathrm{MHz}$, $\left.\mathrm{CDCl}_{3}\right) \delta=1.54 \mathrm{ppm}\left(\mathrm{d},{ }^{3} J_{\mathrm{HH}}=6.6 \mathrm{~Hz}, 6 \mathrm{H}, \mathrm{CH}_{3}-\mathrm{CH}\right), 3.49$ (s, $\left.1 \mathrm{H}, \mathrm{C}_{\mathrm{sp}}-H\right), 5.11\left(\mathrm{sept},{ }^{3} J_{\mathrm{HH}}=6.6 \mathrm{~Hz}, 1 \mathrm{H}, \mathrm{CH}_{3}-\mathrm{CH}-\mathrm{N}\right), 8.33$ (s, $1 \mathrm{H}, \mathrm{N}-\mathrm{CH}-\mathrm{N}) \cdot{ }^{13} \mathrm{C}$ NMR $\left(100 \mathrm{MHz}, \mathrm{CDCl}_{3}\right) \delta=22.12 \mathrm{ppm}$ $\left(+, \mathrm{CH}_{3}-\mathrm{CH}\right), 49.67\left(+, \mathrm{CH}_{3}-\mathrm{CH}-\mathrm{N}\right), 76.19(+), 82.51\left(\mathrm{C}_{\text {quart }}\right)$, $124.93\left(\mathrm{C}_{\text {quart }}\right), 152.45\left(\mathrm{C}_{\text {quart }}\right), 156.08(+), 158.02\left(\mathrm{C}_{\text {quart }}\right) . \mathrm{IR}(\mathrm{film})$ v $3447 \mathrm{~cm}^{-1}, 3307,3221,3069,2984,2109,1651,1595,1567$. Anal. calcd for $\mathrm{C}_{10} \mathrm{H}_{11} \mathrm{~N}_{5}$ : C, 59.69; H, 5.51; N, 34.80. Found C, 59.67; H, 5.46; N, 34.71 .

\section{General procedure B for preparation of triazoles from non-aromatic/benzylic bromides}

3-Ethynyl-1-isopropyl-1 $H$-pyrazolo[3,4- $d$ ]pyrimidin-4-ylamine ( $0.25 \mathrm{mmol}$ ), benzylbromide (1.2 eq.), $\mathrm{NaN}_{3}$ (1.2 eq.), sodium ascorbate $(40 \mathrm{~mol} \%)$ were suspended in of a DMF : $\mathrm{H}_{2} \mathrm{O}(2.5 \mathrm{ml}$, $4: 1)$ mixture in a $2-5 \mathrm{ml}$ microwave vessel. To the stirring mixture $\mathrm{CuSO}_{4}\left(20 \mathrm{~mol} \%\right.$, as a $1 \mathrm{M}$ solution in $\left.\mathrm{H}_{2} \mathrm{O}\right)$ was added and the vessel was sealed and heated to $130{ }^{\circ} \mathrm{C}$ for $30 \mathrm{~min}$ (ramp time: $40 \mathrm{~s}$, pre-stirring: $20 \mathrm{~s}$, high, fixed hold time: on). After cooling to room temperature, the reaction mixture was poured into aqueous ammonia solution $\left(80 \mathrm{ml}\right.$ of $\mathrm{H}_{2} \mathrm{O}, 20 \mathrm{ml}$ of conc. $\left.\mathrm{NH}_{4} \mathrm{OH}\right)$. The layers were separated and the water layer was extracted with EtOAc three times. The combined organic layers were washed with $\mathrm{H}_{2} \mathrm{O}$ and brine and dried over $\mathrm{MgSO}_{4}$. The solvent was removed in vacuo at $30^{\circ} \mathrm{C}$ and the residue was further purified with column chromatography.

\section{4-Amino-3-(1-benzyl-1 $H$-[1,2,3|triazol-4-yl)-1-isopropyl-1 $H$ - pyrazolo[3,4-d]pyrimidine (6a)}

The general procedure B using $2(50 \mathrm{mg}, 0.248 \mathrm{mmol})$ afforded $71 \mathrm{mg}(86 \%)$ of $\mathbf{6 a}$ as colorless sticky oil. $\mathrm{R}_{\mathrm{f}}\left(\mathrm{MeOH}: \mathrm{CHCl}_{3}=\right.$ $1: 80)=0.04 .{ }^{1} \mathrm{H}$ NMR $\left(400 \mathrm{MHz}, \mathrm{CDCl}_{3}\right) \delta 1.51 \mathrm{ppm}(\mathrm{d}$, $\left.{ }^{3} J_{\mathrm{HH}}=6.6 \mathrm{~Hz}, 6 \mathrm{H}, \mathrm{CH}_{3}-\mathrm{CH}\right), 5.09\left(\mathrm{sept},{ }^{3} J_{\mathrm{HH}}=6.6 \mathrm{~Hz}, 1 \mathrm{H}\right.$, $\left.\mathrm{CH}_{3}-\mathrm{CH}-\mathrm{N}\right), 5.58\left(\mathrm{~s}, 2 \mathrm{H}, \mathrm{N}-\mathrm{CH}_{2}-\mathrm{Ph}\right), 7.30-7.42(\mathrm{~m}, 5 \mathrm{H}, \mathrm{Ph}), 8.06$ (s, $1 \mathrm{H}, \mathrm{C}-\mathrm{CH}-\mathrm{N}), 8.33(\mathrm{~s}, 1 \mathrm{H}, \mathrm{N}-\mathrm{CH}-\mathrm{N}) \cdot{ }^{13} \mathrm{C}$ NMR $(100 \mathrm{MHz}$, $\left.\mathrm{CDCl}_{3}\right) \delta 22.03 \mathrm{ppm}\left(+, \mathrm{CH}_{3}-\mathrm{CH}\right), 48.87\left(+, \mathrm{CH}_{3}-\mathrm{CH}-\mathrm{N}\right), 54.68$ $\left(-, \mathrm{N}-\mathrm{CH}_{2}-\mathrm{Ph}\right), 98.77\left(\mathrm{C}_{\text {quart }}\right), 121.17(+), 128.39(+), 129.18(+)$, $129.41(+), 134.19\left(\mathrm{C}_{\text {quart }}\right), 135.50\left(\mathrm{C}_{\text {quart }}\right), 143.09\left(\mathrm{C}_{\text {quart }}\right), 153.39$ $\left(\mathrm{C}_{\text {quart }}\right), 156.32(+), 158.60\left(\mathrm{C}_{\text {quart }}\right) . \mathrm{IR}(\mathrm{film}) \vee 3439 \mathrm{~cm}^{-1}, 3296$, 3105, 2981, 2934, 1661, 1560.). Anal. Calcd for $\mathrm{C}_{17} \mathrm{H}_{18} \mathrm{~N}_{8}: \mathrm{C}, 61.06$; H, 5.43; N, 33.51. Found C, 60.94; H, 5.40; N, 33.36.

\section{4-Amino-1-isopropyl-3-(1-phenethyl-1 $H$-[1,2,3|triazol-4-yl)- $1 H$ - pyrazolo[3,4-d]pyrimidine (6b)}

The general procedure B using $2(50 \mathrm{mg}, 0.248 \mathrm{mmol})$ afforded $57 \mathrm{mg}(66 \%)$ of $\mathbf{6 b}$ as colorless solid. Mp $197-198{ }^{\circ} \mathrm{C} . \mathrm{R}_{\mathrm{f}}$ $\left(\mathrm{MeOH}: \mathrm{CHCl}_{3}=1: 20\right)=0.30 .{ }^{1} \mathrm{H}$ NMR $\left(400 \mathrm{MHz}, \mathrm{CDCl}_{3}\right)$ $\delta 1.54 \mathrm{ppm}\left(\mathrm{d},{ }^{3} J_{\mathrm{HH}}=7.0 \mathrm{~Hz}, 6 \mathrm{H}, \mathrm{NCH}-\left(\mathrm{CH}_{3}\right)_{2}\right), 3.29(\mathrm{t}$, $\left.{ }^{3} J_{\mathrm{HH}}=7.7 \mathrm{~Hz}, 2 \mathrm{H}\right), 4.66\left(\mathrm{t},{ }^{3} J_{\mathrm{HH}}=7.7 \mathrm{~Hz}, 2 \mathrm{H}\right), 5.13$ (sept, $\left.{ }^{3} J_{\mathrm{HH}}=7.0 \mathrm{~Hz}, 1 \mathrm{H},\left(\mathrm{CH}_{3}\right)_{2}-\mathrm{CH}-\mathrm{N}\right), 6.36$ (bs, $\left.1 \mathrm{H}, \mathrm{NH}-\right), 7.13-$ $7.19(\mathrm{~m}, 2 \mathrm{H}), 7.23-7.35(\mathrm{~m}, 3 \mathrm{H}), 8.01(\mathrm{~s}, 1 \mathrm{H}, \mathrm{N}-\mathrm{CH}-\mathrm{C}), 8.32(\mathrm{~s}$, $1 \mathrm{H}, \mathrm{N}-\mathrm{CH}-\mathrm{N}), 9.48(\mathrm{bs}, 1 \mathrm{H}) .{ }^{13} \mathrm{C}$ NMR $\left(100 \mathrm{MHz}, \mathrm{CDCl}_{3}\right) \delta$
$22.16 \mathrm{ppm}(+), 36.79(-), 48.91(+), 52.16(-), 98.76\left(\mathrm{C}_{\text {quart }}\right), 121.41$ $(+), 127.44(+), 128.79(+), 129.11(+), 135.43\left(\mathrm{C}_{\text {quart }}\right), 136.76$ $\left(\mathrm{C}_{\text {quart }}\right), 142.68\left(\mathrm{C}_{\text {quart }}\right), 153.63\left(\mathrm{C}_{\text {quart }}\right), 156.28(+), 158.77\left(\mathrm{C}_{\text {quart }}\right)$. IR $(\mathrm{KBr}) \vee 3439 \mathrm{~cm}^{-1}, 3282,3117,2978,2932,1652,1601,1561$. Anal. Calcd for $\mathrm{C}_{18} \mathrm{H}_{20} \mathrm{~N}_{8}$ : C, 62.05; H, 5.79; N, 32.16. Found C, 62.18; H, 5.71; N, 32.04 .

\section{General procedure $\mathbf{C}$ for preparation of triazoles from aromatic iodides}

3-Ethynyl-1 -isopropyl-1 $H$-pyrazolo[3,4- $d]$ pyrimidin-4-ylamine $(0.25 \mathrm{mmol})$, aromatic iodide (1.2 eq.), $\mathrm{NaN}_{3}$ (1.44 eq.), L-proline (20 mol\%), $\mathrm{Na}_{2} \mathrm{CO}_{3}\left(20 \mathrm{~mol}^{\%}\right.$ ), sodium ascorbate $(40 \mathrm{~mol} \%)$ were suspended in DMSO : $\mathrm{H}_{2} \mathrm{O}(2.5 \mathrm{ml}, 9: 1)$ mixture in a $2-5 \mathrm{ml}$ microwave vessel. To the stirring mixture $\mathrm{CuSO}_{4}(20 \mathrm{~mol} \%$, as a $1 \mathrm{M}$ solution in $\mathrm{H}_{2} \mathrm{O}$ ) were added and the vessel was sealed and heated to $130{ }^{\circ} \mathrm{C}$ for $30 \mathrm{~min}$ (ramp time: $35 \mathrm{~s}$, pre-stirring: $20 \mathrm{~s}$, high, fixed hold time: on). After cooling to room temperature, the reaction mixture was poured into aqueous ammonia solution ( $80 \mathrm{ml}$ of $\mathrm{H}_{2} \mathrm{O}, 20 \mathrm{ml}$ of conc. $\mathrm{NH}_{4} \mathrm{OH}$ ). The layers were separated and the water layer was extracted with EtOAc three times. The combined organic layers were washed with $\mathrm{H}_{2} \mathrm{O}$ and brine and dried over $\mathrm{MgSO}_{4}$. The solvent was removed in vacuo at $30^{\circ} \mathrm{C}$ and the residue was further purified with column chromatography.

\section{4-Amino-1-isopropyl-3-(1-phenyl-1 $H$-[1,2,3]triazol-4-yl)-1 $H$ - pyrazolo[3,4-d]pyrimidine (6c)}

The general procedure $\mathrm{C}$ using $2(50 \mathrm{mg}, 0.248 \mathrm{mmol})$ afforded $75 \mathrm{mg}(95 \%)$ of $\mathbf{6 c}$ as colorless solid. Mp $251-252{ }^{\circ} \mathrm{C} . \mathrm{R}_{\mathrm{f}}$ $\left(\mathrm{MeOH}: \mathrm{CHCl}_{3}=1: 20\right)=0.30 .{ }^{1} \mathrm{H} \mathrm{NMR}\left(400 \mathrm{MHz}, \mathrm{CDCl}_{3}\right)$ $\delta 1.58 \mathrm{ppm}\left(\mathrm{d},{ }^{3} J_{\mathrm{HH}}=6.6 \mathrm{~Hz}, 6 \mathrm{H}, \mathrm{NCH}-\left(\mathrm{CH}_{3}\right)_{2}\right), 5.18$ (sept, $\left.{ }^{3} J_{\mathrm{HH}}=6.6 \mathrm{~Hz}, 1 \mathrm{H},\left(\mathrm{CH}_{3}\right)_{2}-\mathrm{CH}-\mathrm{N}\right), 6.12(\mathrm{bs}, 1 \mathrm{H}, \mathrm{NH}-), 7.48-$ $7.62(\mathrm{~m}, 3 \mathrm{H}), 7.82-7.86(\mathrm{~m}, 2 \mathrm{H}), 8.35$ (s, 1H, N-CH-N), 8.61 (s, 1H, N-CH-C), 9.44 (bs, 1H, NH-). ${ }^{13} \mathrm{C}$ NMR (100 MHz, $\mathrm{CDCl}_{3}$ ) $\delta 22.24 \mathrm{ppm}(+), 49.06(+), 98.92\left(\mathrm{C}_{\text {quart }}\right), 119.32(+), 120.83(+)$, $129.54(+), 130.16(+), 135.11\left(\mathrm{C}_{\text {quart }}\right), 136.90\left(\mathrm{C}_{\text {quart }}\right), 143.46\left(\mathrm{C}_{\text {quart }}\right)$, $153.78\left(\mathrm{C}_{\text {quart }}\right), 156.41(+), 158.70\left(\mathrm{C}_{\text {quart }}\right) . \mathrm{IR}(\mathrm{KBr}) \vee 3432 \mathrm{~cm}^{-1}$, 3295, 3099, 2983, 2934, 1727, 1663, 1564, 1505. Anal. Calcd for $\mathrm{C}_{16} \mathrm{H}_{16} \mathrm{~N}_{8}$ : C, 59.99; H, 5.03; N, 34.98. Found C, 60.02; H, 5.05; N, 35.01 .

\section{4-Amino-3-[1-(4-fluoro-phenyl)-1 $H$-[1,2,3]triazol-4-yl]-1- isopropyl-1 $H$-pyrazolo[3,4- $d]$ pyrimidine (6d)}

The general procedure $\mathrm{C}$ using $2(50 \mathrm{mg}, 0.248 \mathrm{mmol})$ afforded $53 \mathrm{mg}(65 \%)$ of $\mathbf{6 d}$ as pale yellow solid. Mp $265-266{ }^{\circ} \mathrm{C} . \mathrm{R}_{\mathrm{f}}$ $\left(\mathrm{MeOH}: \mathrm{CHCl}_{3}=1: 20\right)=0.28 .{ }^{1} \mathrm{H} \mathrm{NMR}\left(400 \mathrm{MHz}, \mathrm{CDCl}_{3}\right)$ $\delta 1.58 \mathrm{ppm}\left(\mathrm{d},{ }^{3} \mathrm{~J}_{\mathrm{HH}}=6.6 \mathrm{~Hz}, 6 \mathrm{H}, \mathrm{NCH}-\left(\mathrm{CH}_{3}\right)_{2}\right), 5.17$ (sept, $\left.{ }^{3} J_{\mathrm{HH}}=6.6 \mathrm{~Hz}, 1 \mathrm{H},\left(\mathrm{CH}_{3}\right)_{2}-\mathrm{CH}-\mathrm{N}\right), 6.09$ (bs, 1H, NH-), 7.25-7.32 (m, 2H), 7.79-7.85 (m, 2H), $8.35(\mathrm{~s}, 1 \mathrm{H}, \mathrm{N}-\mathrm{CH}-\mathrm{N}), 8.56(\mathrm{~s}, 1 \mathrm{H}, \mathrm{N}-$ $\mathrm{CH}$-C), 9.38 (bs, 1H). ${ }^{13} \mathrm{C} \mathrm{NMR}\left(100 \mathrm{MHz}, \mathrm{CDCl}_{3}\right) \delta 22.24 \mathrm{ppm}$ $\left(+,-\mathrm{CH}_{3}\right.$, isopropyl), $49.08\left(+,-\mathrm{CH}\right.$, isopropyl), $98.90\left(\mathrm{C}_{\text {quart }}\right)$, $117.19\left(\mathrm{~d},{ }^{2} J_{\mathrm{CF}}=23.1 \mathrm{~Hz}\right.$, “ortho-C", +), $119.48(+), 122.87$ (d, ${ }^{3} J_{\mathrm{CF}}=9.2 \mathrm{~Hz}$, "meta-C", +$), 133.18\left(\mathrm{~d},{ }^{4} J_{\mathrm{CF}}=2.3 \mathrm{~Hz}\right.$, "paraC", $\left.\mathrm{C}_{\text {quart }}\right), 134.96\left(\mathrm{C}_{\text {quart }}\right), 143.62\left(\mathrm{C}_{\text {quart }}\right), 153.80\left(\mathrm{C}_{\text {quart }}\right), 156.42$ $(+), 158.66\left(\mathrm{C}_{\text {quart }}\right), 162.97\left(\mathrm{~d},{ }^{1} J_{\mathrm{CF}}=250.6 \mathrm{~Hz}\right.$, “ipso-C", $\left.\mathrm{C}_{\text {quart }}\right)$. IR $(\mathrm{KBr}) \vee 3432 \mathrm{~cm}^{-1}, 3296,3149,2982,2934,1659,1565,1516$, 1235, 622. Anal. Calcd for $\mathrm{C}_{16} \mathrm{H}_{15} \mathrm{FN}_{8}$ : C, 56.80; H, 4.47; N, 33.12. Found C, 56.88; H, 4.42; N, 33.19. 


\section{4-Amino-3-[1-(4-chloro-phenyl)-1 $H$-[1,2,3]triazol-4-yl]-1- isopropyl-1 $H$-pyrazolo $[3,4-d]$ pyrimidine (6e)}

The general procedure $\mathrm{C}$ using 2 (50 $\mathrm{mg}, 0.248 \mathrm{mmol})$ afforded $53 \mathrm{mg}(60 \%)$ of $6 \mathrm{e}$ as pale yellow solid. ${ }^{1} \mathrm{H}$ NMR $(400 \mathrm{MHz}$, DMSO) $\delta 1.51 \mathrm{ppm}\left(\mathrm{d},{ }^{3} J_{\mathrm{HH}}=6.6 \mathrm{~Hz}, 6 \mathrm{H}\right), 5.08$ (sept, $\left.{ }^{3} J_{\mathrm{HH}}=6.6 \mathrm{~Hz}, 1 \mathrm{H}\right), 7.69-7.75\left(\mathrm{~m}, 2 \mathrm{H}, \mathrm{AA}^{\prime} \mathrm{BB}^{\prime}\right) 8.09$ (bs, 1H), 8.11-8.18 (m, 2H, AA'BB') 8.24 (s, 1H), 8.96 (bs, 1H), 9.42 (s, 1H). ${ }^{13} \mathrm{C}$ NMR (100 MHz, DMSO) $\delta 21.77 \mathrm{ppm}(+), 48.47$ (+), $97.83\left(\mathrm{C}_{\text {quart }}\right), 120.75(+), 122.34(+), 129.92(+), 133.64\left(\mathrm{C}_{\text {quart }}\right)$, $134.25\left(\mathrm{C}_{\text {quart }}\right), 135.15\left(\mathrm{C}_{\text {quart }}\right), 142.47\left(\mathrm{C}_{\text {quart }}\right), 153.24\left(\mathrm{C}_{\text {quart }}\right), 156.21$ $(+), 158.24\left(\mathrm{C}_{\text {quart }}\right)$. IR $(\mathrm{KBr}) \vee 3453 \mathrm{~cm}^{-1}(\mathrm{sh}), 3331,3307,3116$, 2977, 2931, 1654, 1565, 1499, 1284, 1257, 587, 509. Anal. Calcd for $\mathrm{C}_{16} \mathrm{H}_{15} \mathrm{ClN}_{8}$ : C, 54.16; H, 4.26; N, 31.58. Found C, 54.20; H, $4.28 ; \mathrm{N}, 31.61$.

\section{4-Amino-3-[1-(4-methoxy-phenyl)-1 $H$-[1,2,3]triazol-4-yl]-1- isopropyl-1 $H$-pyrazolo[3,4- $d]$ pyrimidine (6f)}

The general procedure $\mathrm{C}$ using $2(50 \mathrm{mg}, 0.248 \mathrm{mmol})$ afforded $53 \mathrm{mg}(81 \%)$ of $\mathbf{6 f}$ as pale yellow solid. Mp $261-262{ }^{\circ} \mathrm{C} . \mathrm{R}_{\mathrm{f}}$ $\left(\mathrm{MeOH}: \mathrm{CHCl}_{3}=1: 20\right)=0.30 .{ }^{1} \mathrm{H} \mathrm{NMR}\left(400 \mathrm{MHz}, \mathrm{CDCl}_{3}\right)$ $\delta 1.59 \mathrm{ppm}\left(\mathrm{d},{ }^{3} J_{\mathrm{HH}}=6.6 \mathrm{~Hz}, 6 \mathrm{H}\right), 3.91(\mathrm{~s}, 3 \mathrm{H}), 5.17$ (sept, $\left.{ }^{3} J_{\mathrm{HH}}=6.6 \mathrm{~Hz}, 1 \mathrm{H}\right), 7.06-7.11\left(\mathrm{~m}, 2 \mathrm{H}, \mathrm{AA}^{\prime} \mathrm{BB}^{\prime}\right), 7.71-7.77(\mathrm{~m}, 2 \mathrm{H}$, $\left.\mathrm{AA}^{\prime} \mathrm{BB}^{\prime}\right), 8.35$ (s, 1H), $8.52(\mathrm{~s}, 1 \mathrm{H}) \cdot{ }^{13} \mathrm{C} \mathrm{NMR}\left(100 \mathrm{MHz}, \mathrm{CDCl}_{3}\right) \delta$ $22.23 \mathrm{ppm}\left(+, \mathrm{CHN}-\left(\mathrm{CH}_{3}\right)_{2}\right), 49.15\left(+, \mathrm{CH}_{3}-\mathrm{CH}-\mathrm{CH}_{3}\right), 55.91(+)$, $115.17(+), 119.49(+), 122.47(+), 130.27\left(\mathrm{C}_{\text {quart }}\right), 135.45\left(\mathrm{C}_{\text {quart }}\right)$, $143.14\left(\mathrm{C}_{\text {quart }}\right), 153.58\left(\mathrm{C}_{\text {quart }}\right), 155.73(+), 158.36\left(\mathrm{C}_{\text {quart }}\right), 160.47$ $\left(\mathrm{C}_{\text {quart }}\right) . \mathrm{IR}(\mathrm{KBr}) \vee 3432 \mathrm{~cm}^{-1}, 3302,3114,2988,2935,1656,1606$, 1563, 1517, 1255, 1039, 621. Anal. Calcd for $\mathrm{C}_{17} \mathrm{H}_{18} \mathrm{~N}_{8} \mathrm{O}$ : C 58.27; H 5.18; N 31.98. Found C, 58.30; H, 5.20; N, 32.01.

\section{4-Amino-3-[1-(2-pyridyl)-1 $H$-[1,2,3]triazol-4-yl]-1-isopropyl-1 $H$ - pyrazolo[3,4-d]-pyrimidine (6g)}

The general procedure C using 2 (49 $\mathrm{mg}, 0.244 \mathrm{mmol}$ ) afforded $37 \mathrm{mg}(48 \%)$ of $\mathbf{6 g}$ as yellow solid. $\mathrm{R}_{\mathrm{f}}\left(\mathrm{MeOH}: \mathrm{CHCl}_{3}=\right.$ $1: 20)=0.30 .{ }^{1} \mathrm{H}$ NMR $\left(400 \mathrm{MHz}, \mathrm{CDCl}_{3}\right) \delta 1.58 \mathrm{ppm}(\mathrm{d}$, $\left.{ }^{3} J_{\mathrm{HH}}=6.6 \mathrm{~Hz}, 6 \mathrm{H}\right), 5.17\left(\mathrm{sept},{ }^{3} J_{\mathrm{HH}}=6.6 \mathrm{~Hz}, 1 \mathrm{H}\right), 6.17(\mathrm{bs}$, $1 \mathrm{H},-\mathrm{NH}), 7.39-7.44(\mathrm{~m}, 1 \mathrm{H}), 7.94-8.01(\mathrm{~m}, 1 \mathrm{H}), 8.21-8.25$ (m, 1H), 8.35 (s, 1H), 8.54-8.59 (m, 1H), 9.18 (s, 1H), 9.37 (bs, 1H). ${ }^{13} \mathrm{C} \mathrm{NMR}\left(100 \mathrm{MHz}, \mathrm{CDCl}_{3}\right) \delta 22.23$ ppm (+), $49.04(+), 98.94$ $\left(\mathrm{C}_{\text {quart }}\right), 114.08(+), 118.75(+), 124.32(+), 134.95\left(\mathrm{C}_{\text {quart }}\right), 139.47$ $(+), 143.20\left(\mathrm{C}_{\text {quart }}\right), 149.03(+), 153.73\left(\mathrm{C}_{\text {quart }}\right), 156.27(+), 156.79$ $\left(\mathrm{C}_{\text {quart }}\right), 158.65\left(\mathrm{C}_{\text {quart }}\right)$. IR $(\mathrm{KBr}) \vee 3439 \mathrm{~cm}^{-1}(\mathrm{sh}), 3295,3111,2977$, 2936, 2874, 1663, 1563, 1471, 1031, 775. Anal. Calcd for $\mathrm{C}_{15} \mathrm{H}_{15} \mathrm{~N}_{9}$ (321.1450): C 56.07; H 4.71; N 39.23. Found C,56,10; H, 4.73; N, 39.26 .

4-Amino-3-[1-(3-aminophenyl)-1 $H$-[1,2,3]triazol-4-yl]-1-isopropyl$1 H$-pyrazolo[3,4-d]-pyrimidine (6h)

The general procedure $\mathrm{C}$ using 2 (49 $\mathrm{mg}, 0.244 \mathrm{mmol}$ ) afforded $42 \mathrm{mg}(52 \%)$ of $\mathbf{6 h}$ as pale brownish solid. Mp $262-263{ }^{\circ} \mathrm{C} .{ }^{1} \mathrm{H}$ NMR (400 MHz, DMSO) $\delta 1.51 \mathrm{ppm}\left(\mathrm{d},{ }^{3} J_{\mathrm{HH}}=6.6 \mathrm{~Hz}, 6 \mathrm{H}\right), 5.07$ (sept, $\left.{ }^{3} J_{\mathrm{HH}}=6.6 \mathrm{~Hz}, 1 \mathrm{H}\right), 5.57(\mathrm{bs}, 2 \mathrm{H}), 6.67-6.73(\mathrm{~m}, 1 \mathrm{H}), 7.11-$ $7.16(\mathrm{~m}, 1 \mathrm{H}), 7.19-7.24(\mathrm{~m}, 2 \mathrm{H}), 8.07$ (bs, 1H), 8.24 (s, 1H), 9.02 (bs, 1H), $9.18(\mathrm{~s}, 1 \mathrm{H}) \cdot{ }^{13} \mathrm{C}$ NMR (100 MHz, DMSO) $\delta 21.72 \mathrm{ppm}$ $(+), 48.44(+), 105.20(+), 107.31(+), 114.48(+), 120.18(+), 130.22$ $(+), 134.41\left(\mathrm{C}_{\text {quart }}\right), 137.10\left(\mathrm{C}_{\text {quart }}\right), 142.09\left(\mathrm{C}_{\text {quart }}\right), 150.10\left(\mathrm{C}_{\text {quart }}\right)$,
$153.19\left(\mathrm{C}_{\text {quart }}\right), 156.15(+), 158.25\left(\mathrm{C}_{\text {quart }}\right) . \mathrm{IR}(\mathrm{KBr}) \vee 3439 \mathrm{~cm}^{-1}$, 3370, 2980, 1635, 1563, 1500. Anal. Calcd for $\mathrm{C}_{16} \mathrm{H}_{17} \mathrm{~N}_{9}$ : C, 57.30; H, 5.11; N, 37.59. Found C, 57.34; H, 5.13; N, 38.02.

\section{4-Amino-3-[1-(2-nitrophenyl)-1 $H$-[1,2,3]triazol-4-yl]-1-isopropyl- $1 H$-pyrazolo[3,4-d]-pyrimidine (6i)}

The general procedure $\mathrm{C}$ using 2 (49 $\mathrm{mg}, 0.244 \mathrm{mmol}$ ) afforded $40 \mathrm{mg}(45 \%)$ of $\mathbf{6 i}$ as yellow solid. Mp $256-257{ }^{\circ} \mathrm{C} . \mathrm{R}_{\mathrm{f}}$ $\left(\mathrm{MeOH}: \mathrm{CHCl}_{3}=1: 20\right)=0.35 .{ }^{1} \mathrm{H}$ NMR $\left(400 \mathrm{MHz}, \mathrm{CDCl}_{3}\right) \delta$ $1.57 \mathrm{ppm}\left(\mathrm{d},{ }^{3} J_{\mathrm{HH}}=6.6 \mathrm{~Hz}, 6 \mathrm{H}\right), 5.17\left(\mathrm{sept},{ }^{3} J_{\mathrm{HH}}=6.6 \mathrm{~Hz}\right.$, $1 \mathrm{H}), 6.07$ (bs, 1H, -NH), 7.67-7.72 (m, 1H), 7.75-7.81 (m, 1H), 7.83-7.89 (m, 1H), 8.12-8.19 (m, 1H), $8.36(\mathrm{~s}, 1 \mathrm{H}), 8.48(\mathrm{~s}, 1 \mathrm{H})$, $9.26(\mathrm{bs}, 1 \mathrm{H}) .{ }^{13} \mathrm{C} \mathrm{NMR}\left(100 \mathrm{MHz}, \mathrm{CDCl}_{3}\right) \delta 22.23 \mathrm{ppm}(+), 49.10$ $(+), 98.92\left(\mathrm{C}_{\text {quart }}\right), 122.67(+), 126.07(+), 127.92(+), 130.11\left(\mathrm{C}_{\text {quart }}\right)$, $131.51(+), 134.18(+), 134.60\left(\mathrm{C}_{\text {quart }}\right), 143.56\left(\mathrm{C}_{\text {quart }}\right), 144.75\left(\mathrm{C}_{\text {quart }}\right)$, $153.80\left(\mathrm{C}_{\text {quart }}\right), 156.41(+), 158.59\left(\mathrm{C}_{\text {quart }}\right) . \mathrm{IR}(\mathrm{KBr}) \vee 3432 \mathrm{~cm}^{-1}$ (sh), 3299, 3104, 2980, 2935, 1651, 1609, 1564, 1538, 1352, 1256, 641. Anal. Calcd for $\mathrm{C}_{16} \mathrm{H}_{15} \mathrm{~N}_{9} \mathrm{O}_{2}$ : C, 52.60; H, 4.14; N, 34.50. Found C, 52.63; H, 4.16; N, 34.53.

\section{4-Amino-3-[1-p-tolyl-1 $H$-[1,2,3]triazol-4-yl]-1-isopropyl-1 $H$ - pyrazolo $[3,4-d]$ pyrimidine $(6 \mathbf{j})$}

The general procedure $\mathrm{C}$ using $2(50 \mathrm{mg}, 0.248 \mathrm{mmol})$ afforded $62 \mathrm{mg}(76 \%)$ of $\mathbf{6 j}$ as pale yellow solid. Mp $284-285{ }^{\circ} \mathrm{C} . \mathrm{R}_{\mathrm{f}}$ $\left(\mathrm{MeOH}: \mathrm{CHCl}_{3}=1: 20\right)=0.30 .{ }^{1} \mathrm{H}$ NMR $\left(400 \mathrm{MHz}, \mathrm{CDCl}_{3}\right)$ $\delta 1.59 \mathrm{ppm}\left(\mathrm{d},{ }^{3} J_{\mathrm{HH}}=6.6 \mathrm{~Hz}, 6 \mathrm{H}, \mathrm{CHN}-\left(\mathrm{CH}_{3}\right)_{2}\right), 5.17$ (sept, $\left.{ }^{3} J_{\mathrm{HH}}=6.6 \mathrm{~Hz}, 1 \mathrm{H},\left(\mathrm{CH}_{3}\right)_{2}-\mathrm{CH}-\mathrm{N}\right), 6.01(\mathrm{bs}, 1 \mathrm{H},-\mathrm{NH}), 7.35-7.41$ (m, 2H, $\left.\mathrm{AA}^{\prime} \mathrm{BB}^{\prime}\right), 7.69-7.74$ (m, 2H, AA'BB'), 8.35 (s, 1H, N-CH$\mathrm{N}), 8.56\left(\mathrm{~s}, 1 \mathrm{H},-\mathrm{CH}_{\text {triazol }}\right), 9.48(\mathrm{bs}, 1 \mathrm{H},-\mathrm{NH}) \cdot{ }^{13} \mathrm{C} \mathrm{NMR}(100 \mathrm{MHz}$, $\left.\mathrm{CDCl}_{3}\right) \delta 21.37 \mathrm{ppm}(+), 22.23(+), 49.05(+), 98.90\left(\mathrm{C}_{\text {quart }}\right), 119.30$ $(+), 120.73(+), 130.65(+), 134.61\left(\mathrm{C}_{\text {quart }}\right), 135.22\left(\mathrm{C}_{\text {quart }}\right), 139.77$ $\left(\mathrm{C}_{\text {quart }}\right), 143.30\left(\mathrm{C}_{\text {quart }}\right), 153.77\left(\mathrm{C}_{\text {quart }}\right), 156.40(+), 158.69\left(\mathrm{C}_{\text {quart }}\right) . \mathrm{IR}$ (film) v 3439 (sh) cm $\mathrm{cm}^{-1}, 3298,3098,2980,1663,1560,1520$. Anal. Calcd for $\mathrm{C}_{17} \mathrm{H}_{18} \mathrm{~N}_{8}$ : C, 61.06; H, 5.43; N, 33.51. Found C, 61.14; $\mathrm{H}, 5.37$; N, 33.40.

\section{General procedure D for preparation of triazoles from compound 1}

3 - Iodo - 1 - isopropyl - $1 H$ - pyrazolo[3,4 - $d$ ]pyrimidin - 4 - amine (0.50 mmol), alkyne (1.2 eq.), $\mathrm{NaN}_{3}$ (1.44 eq.), L-proline (20 $\mathrm{mol} \%), \mathrm{Na}_{2} \mathrm{CO}_{3}(20 \mathrm{~mol} \%)$, sodium ascorbate $(40 \mathrm{~mol} \%)$ were suspended in DMSO : $\mathrm{H}_{2} \mathrm{O}(2.5 \mathrm{ml}, 9: 1)$ mixture in a $2-5 \mathrm{ml}$ microwave vessel. To the stirring mixture $\mathrm{CuSO}_{4}(20 \mathrm{~mol} \%$, as a $1 \mathrm{M}$ solution in $\mathrm{H}_{2} \mathrm{O}$ ) were added and the vessel was sealed and heated to $130{ }^{\circ} \mathrm{C}$ for $30 \mathrm{~min}$ (ramp time: $35 \mathrm{~s}$, pre-stirring: $20 \mathrm{~s}$, high, fixed hold time: on). After cooling to room temperature, the reaction mixture was poured into aqueous ammonia solution ( $80 \mathrm{ml}$ of $\mathrm{H}_{2} \mathrm{O}, 20 \mathrm{ml}$ of conc. $\mathrm{NH}_{4} \mathrm{OH}$ ). The layers were separated and the water layer was extracted with EtOAc three times. The combined organic layers were washed with $\mathrm{H}_{2} \mathrm{O}$ and brine and dried over $\mathrm{MgSO}_{4}$. The solvent was removed in vacuo at $30^{\circ} \mathrm{C}$ and the residue was further purified with column chromatography.

\section{4-Amino-3-(4-benzyl-1 $H$-1,2,3-triazol-1-yl)-1-isopropyl-1 $H$ - pyrazolo[3,4-d]pyrimidine (7a)}

The general procedure D using 1 (150 mg, $0.49 \mathrm{mmol})$ afforded $142 \mathrm{mg}(87 \%)$ of $7 \mathbf{a}$ as yellow solid. Mp $247-248{ }^{\circ} \mathrm{C} . \mathrm{R}_{\mathrm{f}}$ 
$\left(\mathrm{MeOH}: \mathrm{CHCl}_{3}=1: 20\right)=0.30 .{ }^{1} \mathrm{H} \mathrm{NMR}\left(400 \mathrm{MHz}, \mathrm{CDCl}_{3}\right)$ $\delta 1.53 \mathrm{ppm}\left(\mathrm{d},{ }^{3} J_{\mathrm{HH}}=6.6 \mathrm{~Hz}, 6 \mathrm{H}\right), 4.20(\mathrm{~s}, 2 \mathrm{H}), 5.16$ (sept, $\left.{ }^{3} J_{\mathrm{HH}}=6.6 \mathrm{~Hz}, 1 \mathrm{H}\right), 6.47(\mathrm{bs}, 1 \mathrm{H}), 7.22-7.39(\mathrm{~m}, 5 \mathrm{H}), 8.19$ (s, $1 \mathrm{H}), 8.35(\mathrm{~s}, 1 \mathrm{H}), 8.77(\mathrm{~s}, 1 \mathrm{H}) .{ }^{13} \mathrm{C} \mathrm{NMR}\left(100 \mathrm{MHz}, \mathrm{CDCl}_{3}\right)$ $\delta=22.04 \mathrm{ppm}(+), 32.35(-), 49.12(+), 92.32\left(\mathrm{C}_{\text {quart }}\right), 119.68(+)$, $127.02(+), 128.99(+), 129.02(+), 137.28\left(\mathrm{C}_{\text {quart }}\right), 138.46\left(\mathrm{C}_{\text {quart }}\right)$, $148.18\left(\mathrm{C}_{\text {quart }}\right), 153.58\left(\mathrm{C}_{\text {quart }}\right), 156.90(+), 157.59\left(\mathrm{C}_{\text {quart }}\right) . \operatorname{IR}(\mathrm{KBr})$ $\mathrm{v}=3453 \mathrm{~cm}^{-1}$ (sh), 3349, 3098, 2978, 2928, 1654, 1568, 617. Anal. Calcd for $\mathrm{C}_{17} \mathrm{H}_{18} \mathrm{~N}_{8}$ : C 61.06; H 5.43; N 33.51. Found C 61.20; H 5.49; N 33.39 .

\section{4-Amino-1-isopropyl-3-(4-phenethyl-1 $H$-1,2,3-triazol-1-yl)-1 $H$ - pyrazolo[3,4-d]pyrimidine (7b)}

The general procedure D using 1 (150 mg, $0.49 \mathrm{mmol})$ afforded $143 \mathrm{mg}(84 \%)$ of $7 \mathbf{b}$ as colorless solid. Mp $187-188{ }^{\circ} \mathrm{C} . \mathrm{R}_{\mathrm{f}}$ $\left(\mathrm{MeOH}: \mathrm{CHCl}_{3}=1: 10\right)=0.36 .{ }^{1} \mathrm{H} \mathrm{NMR}\left(400 \mathrm{MHz}, \mathrm{CDCl}_{3}\right) \delta$ $1.54 \mathrm{ppm}\left(\mathrm{d},{ }^{3} J_{\mathrm{HH}}=6.6 \mathrm{~Hz}, 6 \mathrm{H}\right), 3.05-3.20(\mathrm{~m}, 4 \mathrm{H}), 5.17$ (sept, $\left.{ }^{3} J_{\mathrm{HH}}=6.6 \mathrm{~Hz}, 1 \mathrm{H}\right), 6.87(\mathrm{bs}, 1 \mathrm{H}), 7.17-7.35(\mathrm{~m}, 5 \mathrm{H}), 8.21(\mathrm{~s}$, $1 \mathrm{H}), 8.36$ (s, 1H), 8.77 (bs, 1H). $\left.{ }^{13} \mathrm{C} \mathrm{NMR} \mathrm{(100} \mathrm{MHz,} \mathrm{CDCl}_{3}\right)$ $\delta 22.03 \mathrm{ppm}(+), 27.56(-), 35.42(-), 49.04(+), 92.30\left(\mathrm{C}_{\text {quart }}\right)$, $119.21(+), 126.46(+), 128.58(+), 128.70(+), 137.30\left(\mathrm{C}_{\text {quart }}\right)$, $140.92\left(\mathrm{C}_{\text {quart }}\right), 147.85\left(\mathrm{C}_{\text {quart }}\right), 153.54\left(\mathrm{C}_{\text {quart }}\right), 156.82(+), 157.69$ $\left(\mathrm{C}_{\text {quart }}\right)$. IR $(\mathrm{KBr}) \vee 3432 \mathrm{~cm}^{-1}(\mathrm{sh}), 3332,3138,2980,2929,1653$, 1569, 608. Anal. Calcd for $\mathrm{C}_{18} \mathrm{H}_{20} \mathrm{~N}_{8}$ : C 62.05; H 5.79; N 32.16 . Found C, 62.09; H, 5.81; N, 32.17.

\section{4-Amino-1-isopropyl-3-(4-phenyl[1,2,3]triazol-1-yl)-1 $H$ - pyrazolo[3,4-d]pyrimidine (7c)}

The general procedure D using 1 (90 $\mathrm{mg}, 0.297 \mathrm{mmol})$ afforded $86 \mathrm{mg}(91 \%)$ of $7 \mathrm{c}$ as colorless solid. $\mathrm{Mp}>300{ }^{\circ} \mathrm{C} . \mathrm{R}_{\mathrm{f}}$ $\left(\mathrm{MeOH}: \mathrm{CHCl}_{3}=1: 20\right)=0.30 .{ }^{1} \mathrm{H} \mathrm{NMR}\left(400 \mathrm{MHz}, \mathrm{CDCl}_{3}\right)$ $\delta 1.59 \mathrm{ppm}\left(\mathrm{d},{ }^{3} J_{\mathrm{HH}}=6.6 \mathrm{~Hz}, 6 \mathrm{H}, \mathrm{CHN}-\left(\mathrm{CH}_{3}\right)_{2}\right), 5.22$ (sept, $\left.{ }^{3} J_{\mathrm{HH}}=6.6 \mathrm{~Hz}, 1 \mathrm{H},\left(\mathrm{CH}_{3}\right)_{2}-\mathrm{CH}-\mathrm{N}\right), 6.03(\mathrm{bs}, 1 \mathrm{H},-\mathrm{NH}), 7.39$ 7.54 (m, 3H), 7.95-7.99 (m, 2H), 8.38 (s, 1H, N-CH-N), 8.75 (bs, $1 \mathrm{H},-\mathrm{NH}), 8.75\left(\mathrm{~s}, 1 \mathrm{H}, \mathrm{CH}_{\text {triazol }}\right) .{ }^{13} \mathrm{C} \mathrm{NMR}\left(100 \mathrm{MHz}, \mathrm{CDCl}_{3}\right)$ $\delta=22.13 \mathrm{ppm}(+), 49.24(+), 92.45\left(\mathrm{C}_{\text {quart }}\right), 117.49(+), 126.23(+)$, 129.16(+), 129.28(+), 129.70 $\left(\mathrm{C}_{\text {quart }}\right), 137.14\left(\mathrm{C}_{\text {quart }}\right), 148.19\left(\mathrm{C}_{\text {quart }}\right)$, $153.77\left(\mathrm{C}_{\text {quart }}\right), 157.09(+), 157.54\left(\mathrm{C}_{\text {quart }}\right) . \mathrm{IR}(\mathrm{KBr}) \vee 3448 \mathrm{~cm}^{-1}$, 3339, 3101, 1658, 1567, 1584. Anal. Calcd for $\mathrm{C}_{16} \mathrm{H}_{16} \mathrm{~N}_{8}$ : C, 59.99; H, 5.03; N, 34.98. Found C, 60.02; H, 5.05; N, 35.01.

\section{4-Amino-1-isopropyl-3-[4-(4-methoxyphenyl)-1 $H$-1,2,3-triazol-1- yl]-1 $H$-pyrazolo[3,4-d]pyrimidine (7d)}

The general procedure D using 1 (150 mg, $0.49 \mathrm{mmol})$ afforded $134 \mathrm{mg}(78 \%)$ of $7 d$ as colorless solid. Mp 282-283 ${ }^{\circ} \mathrm{C} . \mathrm{R}_{\mathrm{f}}$ $\left(\mathrm{MeOH}: \mathrm{CHCl}_{3}=1: 20\right)=0.30 .{ }^{1} \mathrm{H} \mathrm{NMR}\left(400 \mathrm{MHz}, \mathrm{CDCl}_{3}\right)$ $\delta 1.59 \mathrm{ppm}\left(\mathrm{d},{ }^{3} J_{\mathrm{HH}}=6.6 \mathrm{~Hz}, 6 \mathrm{H}\right), 3.89(\mathrm{~s}, 3 \mathrm{H}), 5.21$ (sept, $\left.{ }^{3} J_{\mathrm{HH}}=6.6 \mathrm{~Hz}, 1 \mathrm{H}\right), 5.93(\mathrm{bs}, 1 \mathrm{H}), 7.01-7.06\left(\mathrm{~m}, 2 \mathrm{H}, \mathrm{AA}^{\prime} \mathrm{BB}^{\prime}\right)$, 7.86-7.92 (m, 2H, $\left.\mathrm{AA}^{\prime} \mathrm{BB}^{\prime}\right), 8.38$ (s, 1H), 8.66 (s, 1H), 8.77 (bs, $1 \mathrm{H}) .{ }^{13} \mathrm{C}$ NMR $\left(100 \mathrm{MHz}, \mathrm{CDCl}_{3}\right) \delta 22.13 \mathrm{ppm}(+), 49.20(+)$, $55.62(+), 92.44\left(\mathrm{C}_{\text {quart }}\right), 114.69(+), 116.63(+), 122.35\left(\mathrm{C}_{\text {quart }}\right)$, $127.59(+), 137.19\left(\mathrm{C}_{\text {quart }}\right), 148.07\left(\mathrm{C}_{\text {quart }}\right), 153.78\left(\mathrm{C}_{\text {quart }}\right), 157.13$ $(+), 157.53\left(\mathrm{C}_{\text {quart }}\right), 160.42\left(\mathrm{C}_{\text {quart }}\right) . \mathrm{IR}(\mathrm{KBr}) \vee 3424 \mathrm{~cm}^{-1}(\mathrm{sh})$, 3340, 3103, 2989, 2936, 1650, 1569, 1492, 1251. Anal. Calcd for $\mathrm{C}_{17} \mathrm{H}_{18} \mathrm{~N}_{8} \mathrm{O}$ : C 58.27; H 5.18; N 31.98. Found C, 58.29; H, 5.20; N, 32.01 .
4-Amino-1-isopropyl-3-[4-(4-methylphenyl)-1 H-1,2,3-triazol-1-yl]$1 H$-pyrazolo[3,4-d]pyrimidine (7e)

The general procedure D using 1 (150 mg, $0.49 \mathrm{mmol})$ afforded $148 \mathrm{mg}(90 \%)$ of $7 \mathrm{e}$ as colorless solid. Mp $293-294{ }^{\circ} \mathrm{C} . \mathrm{R}_{\mathrm{f}}$ $\left(\mathrm{MeOH}: \mathrm{CHCl}_{3}=1: 20\right)=0.30 .{ }^{1} \mathrm{H}$ NMR $\left(400 \mathrm{MHz}, \mathrm{CDCl}_{3}\right) \delta$ $1.58 \mathrm{ppm}\left(\mathrm{d},{ }^{3} J_{\mathrm{HH}}=6.6 \mathrm{~Hz}, 6 \mathrm{H}\right), 5.21\left(\mathrm{sept},{ }^{3} J_{\mathrm{HH}}=6.6 \mathrm{~Hz}, 1 \mathrm{H}\right)$, 2.43 (s, 3H), 5.94 (bs, 1H), 7.29-7.34 (m, 2H, AA'BB'), 7.83-7.88 $\left(\mathrm{m}, 2 \mathrm{H}, \mathrm{AA}^{\prime} \mathrm{BB}^{\prime}\right), 8.38$ (s, 1H), $8.71(\mathrm{~s}, 1 \mathrm{H}), 8.76(\mathrm{bs}, 1 \mathrm{H}),{ }^{13} \mathrm{C}$ NMR (100 MHz, $\left.\mathrm{CDCl}_{3}\right) \delta 21.60 \mathrm{ppm}(+), 22.13(+), 49.21(+)$, $91.83\left(\mathrm{C}_{\text {quart }}\right), 117.12(+), 126.14(+), 126.87\left(\mathrm{C}_{\text {quart }}\right), 129.96(+)$, $137.18\left(\mathrm{C}_{\text {quart }}\right), 139.17\left(\mathrm{C}_{\text {quart }}\right), 148.28\left(\mathrm{C}_{\text {quart }}\right), 153.77\left(\mathrm{C}_{\text {quart }}\right), 157.11$ $(+), 157.53\left(\mathrm{C}_{\text {quart }}\right)$. IR $(\mathrm{KBr}) \vee 3439 \mathrm{~cm}^{-1}, 3342,3155,3100,2984$, 2932, 1658, 1579 (sh), 1567, 612. Anal. Calcd for $\mathrm{C}_{17} \mathrm{H}_{18} \mathrm{~N}_{8}$ : C 61.06; H 5.43; N 33.51. Found C, 61.06; H, 5.42; N, 33.54.

\section{4-Amino-3-[4-(3-aminophenyl)-1 $H$-1,2,3-triazol-1-yl]-1-isopropyl- $1 H$-pyrazolo[3,4- $d]$ pyrimidine (7f)}

The general procedure D using 1 (150 mg, $0.49 \mathrm{mmol})$ afforded $95 \mathrm{mg}(58 \%)$ of $7 \mathbf{f}$ as greyish solid. Mp $287-288{ }^{\circ} \mathrm{C} .{ }^{1} \mathrm{H}$ NMR $\left(400 \mathrm{MHz}, \mathrm{CDCl}_{3}\right) \delta 1.58 \mathrm{ppm}\left(\mathrm{d},{ }^{3} J_{\mathrm{HH}}=6.6 \mathrm{~Hz}, 6 \mathrm{H}\right), 5.21$ (sept, $\left.{ }^{3} J_{\mathrm{HH}}=6.6 \mathrm{~Hz}, 1 \mathrm{H}\right), 3.83(\mathrm{bs}, 2 \mathrm{H}), 5.99(\mathrm{bs}, 1 \mathrm{H}), 6.69-6.79(\mathrm{~m}$, 1H), 7.20-7.38 (m, 3H), 8.38 (s, 1H), $8.70(\mathrm{~s}, 1 \mathrm{H}), 8.76$ (bs, 1H). ${ }^{13} \mathrm{C}$ NMR (100 MHz, $\left.\mathrm{CDCl}_{3}\right) \delta 22.13$ ppm (+), $49.22(+), 92.44$ $\left(\mathrm{C}_{\text {quart }}\right), 112.57(+), 115.83(+), 116.54(+), 117.51(+), 130.25(+)$, $130.62\left(\mathrm{C}_{\text {quart }}\right), 137.16\left(\mathrm{C}_{\text {quart }}\right), 147.25\left(\mathrm{C}_{\text {quart }}\right), 148.31\left(\mathrm{C}_{\text {quart }}\right), 153.76$ $\left(\mathrm{C}_{\text {quart }}\right), 157.06(+), 157.50\left(\mathrm{C}_{\text {quart }}\right) . \mathrm{IR}(\mathrm{KBr}) \vee 3451 \mathrm{~cm}^{-1}, 3370$, $3128,2985,1655,1616,1567$. Anal. Calcd for $\mathrm{C}_{16} \mathrm{H}_{17} \mathrm{~N}_{9}$ : C 57.30; H 5.11; N 37.59. Found C,57.32; H, 5.13; N, 38.02.

\section{4-Amino-1-isopropyl-3-[4-(2-nitrophenyl)-1 H-1,2,3-triazol-1-yl]- $1 \mathrm{H}$-pyrazolo[3,4-d]pyrimidine (7g)}

The general procedure D using $1(150 \mathrm{mg}, 0.49 \mathrm{mmol})$ afforded $120 \mathrm{mg}(67 \%)$ of $7 \mathrm{~g}$ as colorless solid. Mp 245-246 ${ }^{\circ} \mathrm{C}$. $\mathrm{R}_{\mathrm{f}}$ $\left(\mathrm{MeOH}: \mathrm{CHCl}_{3}=1: 40\right)=0.29 .{ }^{1} \mathrm{H}$ NMR $\left(400 \mathrm{MHz}, \mathrm{CDCl}_{3}\right) \delta$ $1.58 \mathrm{ppm}\left(\mathrm{d},{ }^{3} J_{\mathrm{HH}}=6.6 \mathrm{~Hz}, 6 \mathrm{H}\right), 5.21\left(\mathrm{sept},{ }^{3} J_{\mathrm{HH}}=6.6 \mathrm{~Hz}\right.$, $1 \mathrm{H}), 6.37$ (bs, 1H), 7.57-7.63 (m, 1H), 7.71-7.76 (m, 1H), 7.90$8.03(\mathrm{~m}, 2 \mathrm{H}), 8.38$ (s, 1H), 8.61 (bs, $1 \mathrm{H}), 8.75(\mathrm{~s}, 1 \mathrm{H}) .{ }^{13} \mathrm{C} \mathrm{NMR}$ $\left(100 \mathrm{MHz}, \mathrm{CDCl}_{3}\right) \delta 22.09 \mathrm{ppm}(+), 49.32(+), 92.44\left(\mathrm{C}_{\text {quart }}\right), 120.59$ $(+), 124.00\left(\mathrm{C}_{\text {quart }}\right), 124.65(+), 129.98(+), 131.43(+), 132.93(+)$, $136.77\left(\mathrm{C}_{\text {quart }}\right), 143.03\left(\mathrm{C}_{\text {quart }}\right), 148.68\left(\mathrm{C}_{\text {quart }}\right), 153.73\left(\mathrm{C}_{\text {quart }}\right), 157.04$ $(+), 157.48\left(\mathrm{C}_{\text {quart }}\right) . \mathrm{IR}(\mathrm{KBr}) \vee 3381 \mathrm{~cm}^{-1}, 3189,3151,2987,2934$, 1653, 1582, 1563, 1527. Anal. Calcd for $\mathrm{C}_{16} \mathrm{H}_{15} \mathrm{~N}_{9} \mathrm{O}_{2}$ : C 52.60; $\mathrm{H}$ 4.14; N 34.50. Found Found C 52.45; H 4.20; N 34.42.

\section{4-Amino-1-isopropyl-3-[4-(2-pyridyl)-1 $H$-1,2,3-triazol-1-yl]-1 $H$ - pyrazolo[3,4-d]pyrimidine (7h)}

The general procedure D using 1 (150 mg, $0.49 \mathrm{mmol})$ afforded $122 \mathrm{mg}(78 \%)$ of $7 \mathrm{~h}$ as colorless solid. Mp 247-248 ${ }^{\circ} \mathrm{C} . \mathrm{R}_{\mathrm{f}}$ $\left(\mathrm{MeOH}: \mathrm{CHCl}_{3}=1: 40\right)=0.29 .{ }^{1} \mathrm{H}$ NMR $\left(400 \mathrm{MHz}, \mathrm{CDCl}_{3}\right) \delta$ $1.57 \mathrm{ppm}\left(\mathrm{d},{ }^{3} J_{\mathrm{HH}}=6.6 \mathrm{~Hz}, 6 \mathrm{H}\right), 5.20\left(\mathrm{sept},{ }^{3} J_{\mathrm{HH}}=6.6 \mathrm{~Hz}, 1 \mathrm{H}\right)$, 6.32 (bs, 1H), 7.29-7.36 (m, 1H), 7.81-7.89 (m, 1H), 8.20-8.26 (m, 1H), 8.38 (s, 1H), 8.67 (s, 1H,), 8.68 (s, 1H), $9.14(\mathrm{~s}, 1 \mathrm{H})$. ${ }^{13} \mathrm{C}$ NMR (100 MHz, $\left.\mathrm{CDCl}_{3}\right) \delta 22.12 \mathrm{ppm}(+), 49.17(+), 92.46$ $\left(\mathrm{C}_{\text {quart }}\right), 120.09(+), 120.72(+), 123.74(+), 136.93\left(\mathrm{C}_{\text {quart }}\right), 137.29$ $(+), 148.68\left(\mathrm{C}_{\text {quart }}\right), 149.49\left(\mathrm{C}_{\text {quart }}\right), 149.99(+), 153.73\left(\mathrm{C}_{\text {quart }}\right), 157.02$ $(+), 157.54\left(\mathrm{C}_{\text {quart }}\right)$. IR $(\mathrm{KBr}) \vee 3340 \mathrm{~cm}^{-1}, 3190,3097,2976,1658$, 
1579, 1565, 1528. Anal. Calcd $\mathrm{C}_{15} \mathrm{H}_{15} \mathrm{~N}_{9}$ : C 56.07; H 4.71; N 39.23. Found C 56.15; H 4.12; N 39.16.

\section{PfPK7 inhibition assays}

Recombinant PfPK7 was expressed in E. coli as a glutathione-Stransferase fusion protein and purified as described previously. ${ }^{20}$ Kinases assays were performed in a standard reaction $(30 \mu \mathrm{l})$ containing $0.5 \mu \mathrm{g}$ GST-PfPK7, 20mM Tris- $\mathrm{HCl} \mathrm{pH}$ 7,5, 20mM $\mathrm{MgCl}_{2}, 2 \mathrm{mM} \mathrm{MnCl} 2,15 \mu \mathrm{M}$ cold ATP, 2,5 $\mu \mathrm{Ci}$ and $5 \mu \mathrm{g}$ of MBP (Myelin Basic Protein) as a substrate. The compounds were tested at $10 \mu \mathrm{M}$ in the first instance. To determine $\mathrm{IC}_{50}$ values for compounds $\mathbf{6 c}$ and $\mathbf{6 g}$, kinase reactions were performed with a range of concentrations of the inhibitors; the concentration of DMSO vehicle was identical in all reactions (10\% final). All reactions were performed in triplicate and the data indicate the average values $( \pm \mathrm{SD})$. The reaction proceeded for $30 \mathrm{~min}$ at $30{ }^{\circ} \mathrm{C}$ and was stopped by addition of Laemmli buffer. Samples were boiled for $3 \mathrm{~min}$ and analysed by electrophoresis on $12 \%$ SDS-polyacrylamide gels. The gels were dried and subjected to autoradiography and quantification in a phosphorimager.

\section{Acknowledgements}

This work was financed by the European Commission (the CELLCOMPUT project, Contract No 043310). Work in the CD laboratory is supported by INSERM, and by the FP6 (SIGMAL and ANTIMAL projects, BioMalPar Network of Excellence) and FP7 (MALSIG project) programmes of the European Commission.

\section{References}

1 R. Helmut, Chem. Biodivers., 2004, 1, 361-401.

2 A. P. Schmidt, D. R. Lara and D. O. Souza, Pharmacol. Ther., 2007, 116, 401-416.
3 J. J.-L. Liao, J. Med. Chem., 2007, 50, 409-424.

4 A. C. Dar, M. S. Lopez and K. M. Shokat, Chem. Biol., 2008, 15, 1015-1022.

5 Z. Pan, H. Scheerens, S.-J. Li, B. E. Schultz, P. A. Sprengeler, L. C. Burrill, R. V. Mendonca, M. D. Sweeney, K. C. K. Scott, P. G. Grothaus, D. A. Jeffery, J. M. Spoerke, L. A. Honigberg, P. R. Young, S. A. Dalrymple and J. T. Palmer, Chem. Med. Chem, 2007, 2, 58-61.

6 V. V. Rostovtsev, L. G. Green, V. V. Fokin and K. B. Sharpless, Angew. Chem., Int. Ed., 2002, 41, 2596-2599.

7 M. Meldal, C. W. Tornoe and C. Wenzel, Chem. Rev., 2008, 108, 2952 3015.

8 L. V. Lee, M. L. Mitchell, S. J. Huang, V. V. Fokin, K. B. Sharpless and C. H. Wong, J. Am. Chem. Soc., 2003, 125, 9588-9589.

9 Q. Wang, T. R. Chan, R. Hilgraf, V. V. Fokin, K. B. Sharpless and M. G. Finn, J. Am. Chem. Soc., 2003, 125, 3192-3193.

10 A. Brik, J. Muldoon, Y. C. Lin, J. H. Elder, D. S. Goodsell, A. J. Olson, V. V. Fokin, K. B. Sharpless and C. H. Wong, ChemBioChem, 2003, 4, $1246-1248$

$11 \mathrm{P} . \mathrm{Wu}$ and V. V. Fokin, Aldrichimica Acta, 2007, 40, 7-17.

12 A. K. Feldman, B. Colasson and V. V. Fokin, Org. Lett., 2004, 6, $3897-$ 3899.

13 P. Appukkuttan, W. Dehaen, V. V. Fokin and E. Van der Eycken, Org. Lett., 2004, 6, 4223-4225.

14 N. Bouloc, J. M. Large, E. Smiljanic, D. Whalley, K. H. Ansell, C. D. Edlin and J. S. Bryans, Bioorg. Med. Chem. Lett., 2008, 18, 5294-5298.

15 A. Merckx, A. Echalier, K. Langford, A. Sicard, G. Langsley, J. Joore, C. Doerig, M. Noble and J. Endicott, Structure, 2008, 16, 228-238.

16 A. R. Renslo and J. H. McKerrow, Nat. Chem. Biol., 2006, 2, 701-710.

17 R. G. Ridley, Microbes Infect., 2002, 4, 155-156.

18 C. Doerig, O. Billker, D. Pratt and J. Endicott, Biochimica et Biophysica Acta (BBA) - Proteins \& Proteomics, 2005, 1754, 132-150.

19 P. Pattanaik, J. Raman and H. Balaram, Curr. Top. Med. Chem., 2002, 2, 483-505.

20 D. Dorin, J.-P. Semblat, P. Poullet, P. Alano, J. P. D. Goldring, C. Whittle, S. Patterson, D. Chakrabarti and C. Doerig, Molecular Microbiology, 2005, 55, 184-186.

21 J. C. Kissinger, B. P. Brunk, J. Crabtree, M. J. Fraunholz, B. Gajria, A. J. Milgram, D. S. Pearson, J. Schug, A. Bahl, S. J. Diskin, H. Ginsburg, G. R. Grant, D. Gupta, P. Labo, L. Li, M. D. Mailman, S. K. McWeeney, P. Whetzel, C. J. Stoeckert and D. S. Roos, Nature, 2002, 419, 490-492.

22 D. Dorin-Semblat, A. Sicard, C. Doerig, L. Ranford-Cartwright and C. Doerig, Eukaryot. Cell, 2008, 7, 279-285.

23 Glide [4.0], Schrödinger, LLC., New York, 2005.

24 Macromodel [9.1], Schrödinger, LLC., New York, 2007. 